\title{
Modeling collaborative intentions and behavior in Digital Environments: The case of a Massive Open Online Course (MOOC)
}

\author{
Razmerita, Liana Virginia; Kirchner, Kathrin; Hockerts, Kai; Tan, Chee-Wee
}

\section{Published in:}

Academy of Management Learning and Education

Link to article, DOI:

10.5465/amle.2018.0056

Publication date:

2020

Document Version

Peer reviewed version

Link back to DTU Orbit

Citation (APA):

Razmerita, L. V., Kirchner, K., Hockerts, K., \& Tan, C-W. (2020). Modeling collaborative intentions and behavior in Digital Environments: The case of a Massive Open Online Course (MOOC). Academy of Management Learning and Education, 19(4). https://doi.org/10.5465/amle.2018.0056

\section{General rights}

Copyright and moral rights for the publications made accessible in the public portal are retained by the authors and/or other copyright owners and it is a condition of accessing publications that users recognise and abide by the legal requirements associated with these rights.

- Users may download and print one copy of any publication from the public portal for the purpose of private study or research.

- You may not further distribute the material or use it for any profit-making activity or commercial gain

- You may freely distribute the URL identifying the publication in the public portal 
Modeling collaborative intentions and behavior in Digital Environments: The case of a Massive Open Online Course (MOOC)

\begin{tabular}{|c|c|}
\hline Journal: & Academy of Management Learning \& Education \\
\hline Manuscript ID & AMLE-2018-0056-RES.R4 \\
\hline Manuscript Type: & Research \& Reviews \\
\hline Submission Keywords: & $\begin{array}{l}\text { Collaboration, Collaborative instruction; partnerships, Distance learning, } \\
\text { E-Collaboration, E-learning, Entrepreneurship Education, Future of } \\
\text { Management Education, Learning under conditions of rapid change, } \\
\text { Lifelong development and learning, On-line learning, Pedagogy }\end{array}$ \\
\hline Abstract: & $\begin{array}{l}\text { Modern management education promotes active learning and peer } \\
\text { interaction through group work regarding it as a critical aspect of the } \\
\text { learning process. Given the rise of Massive Open Online Courses } \\
\text { (MOOCs) it is imperative to comprehend how collaboration can be } \\
\text { fostered in such digital learning environments. Synthesizing theories on } \\
\text { individual cognition and collective interaction, we advance a research } \\
\text { model of individual and communal beliefs about collaboration as salient } \\
\text { drivers of collaborative intentions. Analytical results indicate that } \\
\text { attitudes toward collaboration at the outset of the course are predicted } \\
\text { by collaborative outcome expectancy and communal support expectancy, } \\
\text { which in turn are precipitated on participants' perceived ability to work in } \\
\text { groups (collaborative process efficacy) and peer influence (communal } \\
\text { influence). Additionally, we show that collaborative intentions influence } \\
\text { collaborative behavior and its outcomes. In particular we find that group } \\
\text { work engagement contributes to three outcomes: a higher course } \\
\text { retention of participants, increased production of novel ideas and finally } \\
\text { a better learning experience. The models are validated with survey data } \\
\text { collected from a MoOC course. Findings from our study unravel } \\
\text { individual and communal factors affecting engagement in collaborative } \\
\text { processes and show the impact of collaboration on learning and behavior } \\
\text { within online learning environments. }\end{array}$ \\
\hline
\end{tabular}




\title{
Modeling Collaborative Intentions and Behavior in Digital Learning Environments: The Case of a Massive Open Online Course (MOOC)
}

\author{
Liana Razmerita \\ Associate Professor \\ Copenhagen Business School
}

Department of Management, Society and Communication

Dalgas Have 15, 2000 Frederiksberg, Denmark

Tel. +45 3815 2182, Email: 1ra.msc@,cbs.dk

Kathrin Kirchner

Associate Professor, $\mathrm{PhD}$

Technical University of Denmark

Department of Technology, Management and Economics Akademivej, Building 358, 2800 Kgs. Lyngby, Denmark

Tel. +45 452560 32, Email: kakir@,dtu.dk

Kai Hockerts

Professor, PhD

Copenhagen Business School

Department of Management, Society and Communication

Dalgas Have 15, 2000 Frederiksberg, Denmark

Tel. +45 3815 2182, Email: kho.msc@,cbs.dk

Chee-Wee Tan

Professor, $\mathrm{PhD}$

Copenhagen Business School

Department of Digitalization

Howitzvej 60, 2000 Frederiksberg

Tel: +45 3815 4468, Email: ct.digi@cbs.dk

Acknowledgment - We thank the associate editor and the anonymous reviewers for their guidance and support in improving the quality of the manuscript along the different rounds of reviews. Furthermore, we thank our colleagues from COG Cluster at Copenhagen Business School, especially Maribel Blasco, Minna Paunova, Dan Kärreman, and the IPM Group at Technical University of Denmark for their feedback on earlier versions of the paper. We would like to thank to the Sino-Danish Center for their support on this publication. We would 
also like to thank Inger Mees for proofreading. We acknowledge that earlier versions of this article were presented at HICSS and AoM conferences in 2018 


\title{
Modeling Collaborative Intentions and Behavior in Digital Learning Environments: The Case of a Massive Open Online Course (MOOC)
}

\begin{abstract}
Modern management education promotes active learning and peer interaction through group work regarding it as a critical aspect of the learning process. Given the rise of Massive Open Online Courses (MOOCs) it is imperative to comprehend how collaboration can be fostered in such digital learning environments. Synthesizing theories on individual cognition and collective interaction, we advance a research model of individual and communal beliefs about collaboration as salient drivers of collaborative intentions. Analytical results indicate that attitudes toward collaboration at the outset of the course are predicted by collaborative outcome expectancy and communal support expectancy, which in turn are precipitated on participants' perceived ability to work in groups (collaborative process efficacy) and peer influence (communal influence). Additionally, we show that collaborative intentions influence collaborative behavior and its outcomes. In particular we find that group work engagement contributes to three outcomes: a higher course retention of participants, increased production of novel ideas and finally a better learning experience. The models are validated with survey data collected from a MOOC course. Findings from our study unravel individual and communal factors affecting engagement in collaborative processes and show the impact of collaboration on learning and behavior within online learning environments.
\end{abstract}




\section{INTRODUCTION}

Massive Open Online Courses (MOOCs) represent a novel pedagogical approach of delivering business education in the digital age (Whitaker, New, \& Ireland, 2016). MOOCs are Online Learning Environments (OLE) that offer open large scale access to cutting edge courses that will reduce the cost of university education (Fischer, 2014). By providing pedagogical materials (e.g., lecture slides and video recordings) online, MOOCs have empowered individuals, who are dispersed globally, to learn independently at their own pace. They are purported to democratize access to education by broadcasting online instructional content to participants worldwide regardless of geographical and/or temporal boundaries (Jona \& Naidu, 2014; Yuan \& Powell, 2013). MOOCs have been heralded as a major disruptive innovation that could drastically transform the future of management education that has otherwise remained stagnant over the last decades.

However, the euphoria surrounding MOOCs has abated due to several important limitations and challenges for participants, which lead to low retention and a notable decline in participants' enrollment over time (Reich \& Ruipérez-Valiente, 2019). Due to a greater emphasis on independent learning, MOOCs demand a higher level of self-discipline than that of traditional classroom settings thus favoring an older audience that often already holds a first degree (Jordan, 2014; Reich \& Ruipérez-Valiente, 2019). An additional core challenge for MOOC participants is the absence or the limited social interaction and communication with the educator and peer learners (Brahimi \& Sarirete, 2015; Hood, Littlejohn, \& Milligan, 2015). MOOCs fail to provide a social environment that supports collaboration and social interaction, which is important for actively engaging the participants and reducing attrition over time (Rothkrantz, 2015).

Modern management education relies on group work as a means of cultivating skills in critical and analytical thinking by getting learners to work collaboratively and solve cases and real-life business problems. Participant interaction, in the form of communication, negotiation, and joint deliberation on a given problem is an essential component of collaborative learning (McAlpine, 2000). This implies that a lack of peer interaction could pose a hurdle for management education in which critical reflection is possibly just as important as the mere transfer of domain knowledge (Blasco, 2012; Mondahl \& Razmerita, 2014; Moosmayer, 2012). Achieving successful collaborative outcomes necessitates interaction among learners (Garvin, 2003), which naturally flourishes best in learning environments that support social interaction (Barbera, Bernhard, Nacht, \& McCann, 2015; Kolb \& Kolb, 2005; Zhu, Rooney, \& Phillips, 
2016). Group work associated with problem-based learning (e.g. case studies, business plan writing) fosters higher level of cognitive skills (such as explaining, relating, applying) and higher levels of engagement (Biggs \& Tang, 2011).

Consequently, we posit that group work among globally distributed participants in OLE, such as MOOCs, should constitute a critical component of the online learning pedagogy, if educators are to go beyond instruction or the mere dissemination of information via video recordings of lectures. While many OLEs and MOOCs support some kind of collaborative learning via access to discussion boards this alone does not constitute group work, which we define in this paper as "students working together in a group small enough so that everyone can participate on a clearly assigned learning task [carrying] out their tasks without direct supervision of the teacher" (Cohen \& Lotan, 2014).

Moreover, collaboration may foster social constructivist learning environments in which "training participants learn from instructors, participants learn from each other, and the instructor learns from participant” (Kraiger, 2008). Yet, despite its merits, past studies have accentuated that many learners show little or no motivation to engage in group work, especially in online learning environments (Smith et al., 2011; Turel \& Zhang, 2011).

As the success of online learning environments such as MOOCs depends on their successful adoption and continuous use, it is crucial to understand the influencing factors that lead to the desired learning outcomes. The integration of virtual communities (e.g. through group work) into online learning platforms can lead to better outcomes and engagement (Panigrahi, Srivastava, \& Sharma, 2018). So far little is known about how to support group work collaboration in MOOC environments (Wen, Yang, \& Rosé, 2015). But we know that through group work, learners can seek peer support in times of difficulty (Li, Verma, Skevi, Guillaume, \& Dillenbourg, 2014). A better understanding of which factors affect group work and the intention to collaborate will encourage group learning in online environments, which will increase the intention to stay in the course (retention) and thus improve learning outcomes (Zhang et al., 2016).

This study not only heeds the plea of management education researchers to investigate emerging contexts of online education (Arbaugh, Dearmond, \& Rau, 2013; Whitaker et al., 2016), but also responds to their call for more quantitative studies on potential moderators influencing collaboration (Garrison \& Arbaugh, 2007). To this end, we explore both the factors affecting participants' willingness to engage in online collaboration through optional group work and the outcomes of such behavior. By synthesizing theories of individual cognition and collective interaction, this study assimilates both individual and communal factors in 
explaining how online collaborative intentions could be induced. Particularly, we advance a research model that delineates individual and communal factors that affect one's attitude and intention to collaborate online. The Model of Online Collaborative Intention contributes to an understanding of factors that lead to intention to engage in collaboration or not. Our model posits direct determinants of intentions to join group work and proposes significant moderating influences of Negative Collaborative Experience (NCE) and Collaborative Technology Experience (CTE).

Furthermore, in a second stage based on data collected at the end of the course we show that a priori intentions lead to actual behavior and engagement in group work. In a post intention model we show how intention impacts group work engagement that in turn leads to retention of participants in the course, generation of new ideas as output of collaborative work, and an enhanced learning experience. The post intention model conceptualizes and tests key factors that impact collaboration in online learning environments such as MOOCs. Our research models are validated based on data gathered from MOOC participants at the beginning and at the end of the course. Most of the studies stop at pre-intention level and do not further test whether intention leads to intended behavior. To our knowledge this is one of the first studies that also investigates post intention behavior, thus bridging the intention behavior gap.

The paper is structured as follows: we first review related work that forms the basis for our research model. Next, we introduce our proposed research model on online collaborative intention and derive testable hypotheses. After this, we describe the methodological procedures for data collection and analysis before presenting the analytical results. Finally, we conclude with implications of our work for theory and practice, highlight potential limitations of our work, and outline avenues for future research.

\section{COLLABORATION IN DIGITAL LEARNING ENVIRONMENTS: A THEORETICAL OVERVIEW}

Next, we will outline extant research on collaboration in OLEs and then discuss research streams related to collaboration and group work in MOOCs particularly.

\subsection{Collaboration in Online Learning Environments}

Since the early 1970s, collaborative learning has become an increasingly important pedagogical technique (Dillenbourg, 1999; Ku, Tseng, \& Akarasriworn, 2013) where learners work together in small groups to solve a common task (Prince, 2004). Collaborative learning is characterized by a shared responsibility for group work and an emphasis on development of 
personal and social skills. Group work should aim for consensus building rather than completion among group members (Blasco \& Tackney, 2013). While early research into collaborative learning was centered on face-to-face encounters, there has been a gradual shift in scholarly attention toward a deeper understanding of online learning environments, especially with respect to virtual collaboration among globally distributed learners (Arbaugh et al., 2013; Clark \& Gibb, 2006; Taras et al., 2013).

Collaboration in online courses, such as MOOCs, requires learners to be autonomous and self-directed with minimal guidance from the teacher (Rienties et al., 2012) and therefore they need to be motivated to engage actively in group work and classroom activities. The mediated nature of online learning is an important limitation of online courses as students may not develop "a sense of belonging" with other participants and instructors (Swan \& Shih, 2005) in such an environment. Such a sense of belonging with other students could be addressed through social interactions taking place in online communities and group work. Collaborative learning strategies promote the feeling of connectedness, belonging and satisfaction and are therefore critical in online environments (Haythornthwaite, 2006; So \& Brush, 2008).

Collaborative learning is an invaluable pedagogical tool for management education because it not only enables learners to experience how it feels like to function as a team member, but more importantly, it proffers a safe environment for acquiring requisite competencies for future work life (Rafferty, 2013). Through group work, learners can hone their skills in collaborating (e.g., giving and receiving feedback as well as helping peers in need), interpersonal networking (e.g. practicing inclusivity, putting others at ease, building trust and resolving conflicts), organizing (e.g., chairing and coordinating meetings as well as workflow planning), and problem-solving (e.g. brainstorming, devising and negotiating alternatives as well as implementing and evaluating consensual solutions) (Ettington \& Camp, 2002). Collaboration through group work promote active learning and co-construction of knowledge, but such peer-to-peer exchanges depend on time, individual contribution and trust among peers (Haythornthwaite, 2006).

While there are benefits of group work in engendering peer learning (Kreijns, Kirschner, \& Jochems, 2003), there are also drawbacks, especially in digital learning environments where learners hardly ever have an opportunity to meet face-to-face. Due to geographical and temporal constraints, learners not only find the initial group-building process to be tedious and time-consuming, but even after groups have been formed, the scheduling of collaborative work is no easy task due to the necessity for communication and coordination across space and time (Smith et al., 2011). 
Having said that, how to promote knowledge-intensive social interactions among learners continues to be an elusive hurdle that must be overcome before the promise of collaborative learning can be realized in online learning environments (Manathunga \& Hernández-Leo, 2015). Learners often struggle with group work in online learning environments, because they are expected to cooperate with members belonging to heterogeneous cross-cultural teams that span multiple time zones, a novel experience for most people. Due to the asynchronicity of digital learning environments, it is a common expectation of learners that they will mainly be working independently, thereby leading to resistance toward online group work (Smith et al., 2011). Unraveling the factors affecting learners' willingness to engage in group work is hence imperative for the realization of collaborative learning in digital learning environments. Because the interplay between individuals as independent entities and the group as a collective jointly regulates one's motivation to engage in collaborative learning (Järvelä, Volet, \& Järvenoja, 2010), past studies have appealed for further inquiries into the determinants of learners' intention to engage in group work that incorporate both individual and communal considerations (Dillenbourg, 1999; Stahl, Koschmann, \& Suthers, 2006).

\subsection{MOOCs: What we know and what we need to know}

Massive open online courses (MOOCS) constitute one of the most prevalent forms of online learning and they are often considered a disruptive innovation for the educational sector (Reich \& Ruipérez-Valiente, 2019). MOOCs constitute a rich landscape for learning and therefore there are many aspects that need further investigation including: theories and practice covering aspects of formal and informal learning, didactic and experiential learning, peer and master-based mentoring, cognitive and social dimensions of learning (Fischer, 2014).

A study of 76 randomly selected MOOCs investigating the quality of instruction found that only 8 included collaborative learning and that none included course instructor feedback (Margaryan, Bianco, \& Littlejohn, 2015). Truly autonomous group work rarely occurs in traditional MOOCs, where lecturing and passive learning are predominant. Prior research on MOOCs has addressed multi-dimensional aspects of learning such as: instructional design and quality, (Andersen \& Ponti, 2014; Margaryan et al., 2015), pedagogical approaches (Glance, Forsey, \& Riley, 2013) and research challenges in MOOCs (Fischer, 2014; Jona \& Naidu, 2014). Our research aims to cover the latest aspects, namely the integration of the social dimension of learning through group work. An overview of the identified research streams is presented in Table 1. 


\section{--- Insert Table 1: Overview of Primary Research Streams in MOOCs ---}

Research related to MOOCs focusing on students' participation, motivation, intentions and group work in MOOCs can be classified along five main research streams: learners' motivation and strategies, attitudes toward MOOC, MOOC continuance and completion intention, online interaction with other participants inside and outside MOOC, and group work within MOOCs. Group work is acknowledged to be an important aspect for learning and completing a MOOC (Barak, Watted, \& Haick, 2016). Regarding group work, we can distinguish two research streams: group work within MOOCs and associated interaction within MOOCs (e.g. by posting and active participation in discussion forums) or outside MOOCs (e.g. in face-to-face meetings). However apart from the few articles covering group work, research has been rather sparse in this particular topic in MOOCs.

While collaboration using group work in MOOCs can help overcome the lack of interaction with faculty, it can also be a challenge by itself. This is particularly a risk when courses end with dysfunctional teams due to insufficient matching of group members (Staubitz \& Meinel, 2017). Therefore several articles have examined algorithms, criteria, and tools that can be used by instructors to form successful groups (for example the level of activity in the MOOC) (Rothkrantz, 2015; Sanz-Martínez, Martínez-Monés, Bote-Lorenzo, MuñozCristóbal, \& Dimitriadis, 2017; Staubitz \& Meinel, 2017). Females and participants intending to complete the MOOCs are more likely to study in groups than males and participants who do not intend to complete the MOOC (Zhang et al., 2016). Group leaders play an important role both for forming the group and successfully managing group work in MOOC (Wen et al., 2015).

In the second research stream, face-to-face study groups and online interactions in MOOCs discussion forums are investigated. Students who participate in a MOOC meet to watch videos together or discuss the content offline. Group discussions broaden students' perspectives, intensify their motivation for learning, provide a sense of community and allow social comparison with other participants ( $\mathrm{Li}$ et al., 2014). Although discussion threads are short-term only (Gillani \& Eynon, 2014), they may lead to online interactions and relationships between participants (Wise \& Cui, 2018), which in turn may create a sense of belonging to a community.

The third research stream discusses the motivation and learning strategies of MOOC learners. Learners enroll in MOOCs to extend their knowledge, broaden their skills or to get a certificate. During participation, they may feel isolated with no help from instructors or other 
participants (Hew \& Cheung, 2014). Additionally, intrinsic motivation and self-determination are factors for joining and persisting in a MOOC course (Barak et al., 2016).

The fourth research stream is centered around the attitude toward MOOCs. The attitude toward MOOCs participation is generally positive after the MOOC has been completed. A MOOC can offer a "constructive" learning environment and the challenges are manageable. (Shapiro et al., 2017). The perceptions that students may have toward this new technology can influence their decision to participate in MOOCs. Learners' beliefs and their attitudes toward technology determine their intentions to attend and engage in a MOOC course (Zhou, 2016).

The fifth research stream covers intention of students to continue a MOOC. Ease of use, perceived usefulness and self-determination influence the satisfaction with the MOOC and thus positively influence retention (Joo, So, \& Kim, 2018). Self-efficacy, teaching presence and perceived usefulness have also been found to have a positive effect on learning engagement. Learning engagement and active participation such as posting in forums, had in turn a positive effect on continuing a MOOC (Jung \& Lee, 2018). A sense of community and perceived gains from study groups (e.g. cognitive gains, affective gains) were found to influence the attitudes and the behavioral intentions of learners in both general online learning platforms and MOOCs. Additionally, perceived convenience and computer self-efficacy can influence continuance intention for MOOCs, but not for general e-learning (Hsu, Chen, \& Ting, 2018). Many of the papers modelling continuance, revisit, and completion intention of MOOCs draw on the Technology Acceptance Model (TAM) proposed by (Davis, 1989). TAM is a widespread model that considers ease of use and perceived usefulness of technology as antecedents of attitude and behavioral intention.

As described above, recent research has argued for the importance of evaluating intentions in relation with continuance intention to use MOOCs (Alraimi, Zo, \& Ciganek, 2015; Huang, Zhang, \& Liu, 2017) and this has been done independently of studying behavior. However, according to our literature review, so far little empirical research has been done on the factors that influence collaboration in online learning environments and MOOCs. Our research aims to address this gap. Fostering collaboration through group work in MOOCs is necessary to bolster peer learning, peer evaluation, as well as to motivate and retain participants.

Even though research on collaboration has a rich history with multiple theoretical lenses proposed for deriving antecedents of individuals' collaborative intentions (Rafferty, 2013; Turel \& Zhang, 2011), there is a paucity of studies that have examined the phenomenon in the context of large-scale MOOCs with up to thousands of demographically diverse and globally 
dispersed learners. Collaboration depends on the presence of communal ingredients (e.g. shared vision, trust, and interaction) (Mattessich \& Monsey, 1992). Thus, we will synthesize individual cognition and collective interaction theories to advance a research model explaining how individual beliefs about communal attributes affect collaborative intentions in digital learning environments (section 2.3). Section 2.4 introduces theories associated with collaborative behavior (the post-intention model).

\subsection{Pre-Intention Theories: Individual Cognition and Collective Interaction}

This section introduces and discusses the constructs and theories leading to the development of a comprehensive model that integrates fragmented research in collaboration and group work in digital environments and MOOCs. To construct a research model on online collaborative intentions, we draw primarily on established cognitive and behavioral theories of individual and communal learning.

Specifically, we synthesize individual cognitive theories which elucidate the formation of intentions (i.e., Social Cognitive Theory (SCT) and Theory of Planned Behavior (TPB)) with collective interaction theories underlying collaborative learning mechanisms as well as the rationale for collaborative or non-collaborative behavior (i.e., Social Exchange Theory (SET) and Social Interdependence Theory (SIT)). In the following, we will give a brief introduction into each of the four theories before proceeding with the construction of our research model and the formulation of testable hypotheses.

Social Cognitive Theory (SCT), proposed by Bandura $(1989,1991)$ as an adaptation of Bandura and Walters' (1963) Social Learning Theory (SLT), accentuates the role of behavioral observations and emulations for performing a given action (e.g., learning) within a social context. SCT conceives of learning as a cognitive process that is situated within a social context (for example a group or an online community in a MOOC) and resolves around four principal components: modeling of behavior, outcome expectations, self-efficacy and shared commonalities. According to SCT, learning begins with observing how others behave (modeling). Next, behavioral models are linked with beliefs about the consequences that will manifest from performing the action (e.g., outcome expectations); following which, selfefficacy takes effect whereby individuals will draw on previous experiences to assess their own capability of reaching a desired outcome. Finally, SCT predicts that behavior is more likely to be modeled if the person being observed (either the educator or a fellow learner) shares commonalities with the observer. Of the four elements, the SCT places the greatest emphasis 
on the importance of self-efficacy (Bandura, 1977). Self-efficacy beliefs affect cognitive functioning through the joint influence of motivational and information-processing operations.

Self-efficacy is also amenable to the context of online learning because it influences learners' motivation, governing the amount of effort learners are willing to invest in the learning process and the time for which they can persevere when confronted with obstacles (Bandura, 1989). SCT is a popular learning theory rooted in human agency that has been applied also for studying media effects and communication. It models how people learn taking into account both individual self-efficacy and the environment, for example established collective norms in the MOOC and proxy agency. A proxy agency can be another person who secures benefits for the individual (e.g. a teacher or a group member). Thoughts, feelings, motivation and actions affect individual agency (Bandura, 1986). Such individual agency influences both its own course of action, the collective agency and the learning environment (Pajares, Prestin, Chen, \& Nabi, 2009). The agency has four components: intentionality, forethought, self-reactiveness and self-reflectiveness (Bandura, 2006). People exercise collective agency when they work together.

The Theory of Planned Behavior (TPB) (Ajzen, 1991) has emerged as a robust model for predicting intentions and behavior across various domains (Beck \& Ajzen, 1991; Giles, McClenahan, Cairns, \& Mallet, 2004; Kautonen, van Gelderen, \& Tornikoski, 2013). According to TBP and its precursor, the Theory of Reasoned Action (TRA), and one of its most influential extensions, Technology Acceptance Model (TAM), peoples' behavior is rational. This theory helps to explain the mechanism "belief-attitudes-behavioral intention" that leads to a certain behavior. TPB suggests that the attitude serves as an evaluative predisposition toward behavior (Ajzen, 1985). The TPB holds that the formation of individuals' intentions toward performing a given action is shaped by three antecedents: their Attitudes Toward a Behavior (ATB), their perceived Subjective Norms (SN), and their Perceived Behavioral Control (PBC). PBC is usually divided into internal and external control. Whereas internal control is synonymous with individuals' self-efficacy (Bandura, 1977), external control reflects their beliefs about the availability of social endorsement or opposition in the environment (Sarason, Levine, Basham, \& Sarason, 1983; Zimet, Dahlem, Zimet, \& Farley, 1988). “ Efficacy is vital for successful functioning regardless of whether it is achieved individually or by team members working together" (Bandura, 2001:16).

Drawing on Bandura's (1989) work on human agency and Ajzen's (2002) study of Perceived Behavioral Control, past studies on educational psychology have revealed that autonomy in the classroom and a feeling of self-determination (i.e., process by which a person 
controls his/her own actions) promote intrinsically motivated learning whereas teacher-driven external control hinders it (Niemiec \& Ryan, 2009). In the same vein, prior research has documented that learners' need for self-determination serves as a salient driver of their motivation to engage in group work (Liu, Wang, Tan, Koh, \& Ee, 2009). Applied to an online learning context prior research has shown that attitudes, norms and perceived behavioral control all affect intentions to use online tools for learning purposes (Liaw, 2004). In addition, pre-service teachers' self-reported intention to use technology in education is predicted by attitude and social norms (Teo, 2012).

Social Exchange Theory (SET) builds on work by Homans (1958) as well as Thibaut and Kelly (1959). As posited by SET, humans are rational agents that decide to engage in a relationship based on cost-benefit analysis. By evaluating the pros and cons of a relationship, individuals will then decide whether they choose to connect and collaborate with others. SET thus offers clarity on why humans interact with others, and when they seek mutual support in their interactions, relationships, and exchanges. It is a central tenet of SET that individuals are inclined to repeat actions for which they have been rewarded previously. Furthermore, SET includes an assumption of reciprocity, which refers to the mutual reinforcement of the actions of two parties pending the input of the other. In contrast to SET which focuses on a rational choice by the individuals, SCT includes an affective dimension of cognition and learning. Empirical applications of the SET in a learning context have demonstrated that participation in learning networks is indeed based on expectations about rewards just as the SET would predict (Hummel et al., 2005), and that reciprocity expectations can at least partially explain the formation of ties among participants in a MOOC (Kellogg, Booth, \& Oliver, 2014).

Social Interdependence Theory (SIT) expands on SET by shifting the theorization from dyadic to communal behavior (Johnson \& Johnson, 2009). By unpacking the process through which interdependence among individuals steers their relational engagement or lack thereof (Johnson, 1970; Johnson \& Johnson, 1989), SIT has been especially influential in educational research for promoting collaborative learning (Johnson, Johnson, \& Smith, 2007). SIT postulates that positive and negative interdependence dictate the effectiveness of a given action, which in turn trigger psychological processes that impact future interaction patterns, as well as outcomes on both individual and communal levels. In such interactions, following Deutsch $(1949,1962)$, we differentiate between positive interdependence (as a situation where the goal attainment of one individual is linked to another individual attaining their goal) and negative interdependence (as a situation where individuals perceive that in order for them to obtain their goal the other individual has to fail to obtain their goal). Colloquially speaking, positive 
interdependence can be referred to as a perceived "win-win" scenario, whereas a negative interdependence implies a "win-lose" or "zero-sum" type of situation.

Additionally, SIT predicts that the outcomes arising from collaborative efforts tend to be reciprocal in nature. That is, the more effort expended by learners on collaborative work, the greater the enhancements to social competencies and self-esteem, thereby culminating in committed and efficacious relationships that are central to sustaining a learning community (Johnson et al., 2007). Insights gleaned from SET and SIT have been replicated widely, among other domains, to organizational learning in strategic alliances where it has been found that mutual influence, reciprocal commitment, and trust among partners are positively associated with knowledge transfer and learning in strategic alliances (Muthusamy \& White, 2005).

Nevertheless, SET is an overarching theoretical framework that is rather generic and can be applied to any social exchange, even when collaboration is absent. SIT, on the other hand, is geared toward deciphering the impact of social interdependencies on peer interactions and communal outcomes without taking into account the moderating effects of previous experience.

\subsection{Post-Intention Theories: Studying the Effect of Collaborative Learning}

So far, we have mainly been concerned with theories exploring the antecedents of group work intentions in an OLE context. An equally interesting question concerns the effect that group work engagement has on retention, creativity (solutions or ideas generated through group work) and learning outcomes.

At the heart of collaborative learning lies the theory of proximal development (Vygotsky, 1978) which proposes that peer-to-peer learning is a driver of positive learning outcomes (Chaiklin, 2003; Hogan \& Tudge, 1999). Group work fosters a zone of proximal development which allows students to enhance their knowledge and skills if they work together with more capable or knowledgeable peers or peers with complementary knowledge. This proximal development theory is in contrast to traditional learning theories which assume that educators merely transfer abstract concepts. Whitehead (1929) instead proposes that learning is best conceived as a dynamic cyclical rhythm. He emphasizes the role of universities to support the "imaginative consideration of learning" beyond the mere imparting of information. Freire (1970) suggests that learning is a social process through a less structured "dialogic enrichment to effectively ascertain knowledge".

Social learning and the successor social cognitive theory, as presented earlier, posit that students observe, imitate and model the behavior of their peers (Bandura, 1971). Collaborative 
behavior can thus provide the basis for social learning by allowing learners to observe the behavior of peers. Social learning theory suggests that participatory and interactive learning causes adjustments in the basic attributes of learners, outstripping what cognitive knowledge processes can achieve (Gherardi, Nicolini, \& Odella, 1998). Learning relies on collective and interdependent actions in order to create positive learning outcomes (Branzei \& Fredette, 2008; Dewey, 1938).

Prior research on student engagement indicates that group work can increase student participation in a class and increase retention of learning contents (Ames, 1992). Moreover, prior research has demonstrated that lower engagement in school activities is a likely predictor of later school failure. This process has been theorized as the Participation-Identification Model (PIM) (Finn, 1993). PIM conceptualizes the link between school engagement and the risk that students drop out of school. This closed loop model proposes that active participation leads to increased learning outcomes, which in turn increases student identification with the learning subject, and which eventually results in higher participation. A previous review of school engagement studies points out the link between higher engagement and lower drop-out rates (Fredricks, Blumenfeld, \& Paris, 2004).

From this we can surmise that one way of counteracting the low retention rates in MOOCs would be to increase class participation. Dixson (2010), for example, reported that the level of student presence in online courses was significantly correlated with student engagement. While not testing this effect explicitly, she also postulated that "collaborative/interactive activities seem to be a necessary component to effective online instruction" (Dixson, 2010: 13).

Social learning theory has also been applied in the context of creativity research, where it has been used to ascertain that successful collaborative efforts will increase the production of novel and useful ideas (Blohm, Bretschneider, Leimeister, \& Krcmar, 2010; Garfield, Taylor, Dennis, \& Satzinger, 2001). Collaboration, group interaction and creative processes are influenced by individual, social and contextual factors (Paulus \& Nijstad, 2003).

\section{HYPOTHESES FORMULATION}

By synthesizing the theories outlined above, we have developed two sets of hypotheses. A first model centers around the antecedents of OLE group work intentions and a second model provides a set of hypotheses around the outcomes of OLE group work behavior. In the first model we integrate individual cognition (SCT) and collective interaction theories (SIT and SET) to advance a research model of online collaborative intention. Because each of the 
aforementioned theories embodies concepts which resonate with preconditions for collaboration, their synthesis yields a comprehensive view of the factors driving collaborative intentions in digital learning environments.

Figure 1 depicts our first research model where we outline the key drivers and psychological mechanisms shaping individuals' intention to collaborate in digital learning environments. Specifically, we hypothesize that perceived collaborative process efficacy and communal influence affect individuals' expectations of collaborative outcome and communal support respectively. Additionally, we posit that negative collaborative experience will attenuate the relationships between collaborative process efficacy and collaborative outcome expectancy, as well as between communal influence and communal support expectancy.

--- Insert Figure 1 here: Research Model of Antecedents of Online Collaborative Intention ---

In our second model we suggest that group work intentions do indeed predict actual group work behavior, which in turn causes higher course retention, more novel idea generation, and a more positive learning experience.

--- Insert Figure 2 here: Research Model of Behavioral Consequences of Online Collaborative Intention ---

\subsection{Modeling Antecedents of Collaborative Intentions}

Extending Bandura's (1986) conception of individual self-efficacy to the level of group work, we construe Collaborative Process Efficacy (CPE) as the degree to which an individual is confident in their ability to function efficaciously in groups. CPE consequently denotes individuals' judgement of their capabilities to organize and execute collaborative courses of action required to attain designated group performances. In this sense, higher levels of CPE are likely to induce greater expectations of positive collaborative outcome (Bandura, 1986). CPE is related but not the same as Bandura's collective efficacy concept, which is defined as a group 's shared beliefs in its conjoint capabilities to execute the courses of action required to achieve designated goals (Bandura, 1997; Wang \& Lin, 2007). Instead within our article we refer to collaborative process efficacy as an individual perception of the " ability to function efficaciously in a group" (see Annex A).

The relationship between CPE and collaborative outcome expectancy also resonates with the premise of SIT in that "the more individuals work together, the greater tends to be their social competencies, self-esteem, and the more effectively they tend to work together" (Johnson et al., 2007: 22). We therefore hypothesize that: 
Hypothesis 1a: An individual's collaborative process efficacy is related to their collaborative outcome expectancy toward group work.

Next, Collaborative Outcome Expectancy (COE) refers to the degree to which an individual believes that group work is instrumental in achieving tangible outcomes. As aptly surmised by Bandura (1989: 1175), the "ability to envision the likely outcomes of prospective actions is another way in which anticipatory mechanisms regulate human motivation and action [...]. People strive to gain anticipated beneficial outcomes and to forestall aversive ones." The original TPB surmises that attitudes toward behavior and self-efficacy are two independent antecedents of intention formation. We do not agree with that argumentation. Much of technology acceptance research proposes that self-efficacy actually influences intentions only indirectly via attitudes. This has influenced important technology models such as the technology acceptance model (TAM) which has been extensively used in studies of online behavior mediated by technology (Davis, 1989) and recently in MOOC-related research (Hsu et al., 2018). In line with TAM we consider attitude a precursor of intention.

Because COE captures the extent to which learners are assured of the advantages of collaboration in improving learning performance, we anticipate that the presence of COE will induce positive attitudes toward group work. We therefore hypothesize that:

Hypothesis 1b: An individual's collaborative outcome expectancy is related to their collaborative attitude toward group work.

In line with TPB, we also adapt the notion of social norms to the context of our study (Ajzen, 2011). Relabeled as Communal Influence (CI), social norms, when extrapolated to digital learning environments like MOOCs, should reflect the degree to which an individual believes that group work is an expected behavior among their peers (an extension of the social norm concept cf. Fishbein \& Ajzen, 1975). CI is a representation of an individual's normative beliefs about the collaborative attitudes of peers in their immediate environment (Cialdini, Reno, \& Kallgren, 1990). Such beliefs form the basis of expectations about the level of support an individual would be likely to receive from their peers in collaborative work. We therefore hypothesize that:

Hypothesis 2a: An individual's communal influence is related to their communal support expectancy toward group work.

Communal Support Expectancy (CSE) is the degree to which an individual believes that their peers will support their engagement in group work. According to the tenets of SIT, communal behavior and group dynamics are crucial to the success of virtual collaboration. CSE can thus mitigate learners' uncertainty about group work by engendering beliefs about the active participation of collaborators, constructive dialogue among group members, as well as 
the presence of cohesion and trust among peers (Greenlee \& Karanxha, 2010). In particular, prior research has shown that the existence of commonalities and peer familiarity will dictate the willingness of group members to engage in candid conversation and constructive collaboration (Janssen, Erkens, Kirschner, \& Kanselaar, 2009). Adhering to SCT, we deduce that learners' positive outcome expectancy regarding communal support will be associated with their positive attitude toward group work. Likewise, SET suggests that "the more effort students expend in working together, the more they tend to like each other. The more they like each other, the harder they tend to work" (Johnson et al., 2007: 22). We therefore hypothesize that:

Hypothesis $2 \boldsymbol{b}$ : An individual's communal support expectancy is related to their attitude toward group work.

According to TPB, one's attitude toward a given behavior is regulated by a constellation of behavioral beliefs associating the behavior with specific outcomes of interest (Ajzen, 2011; Fishbein \& Ajzen, 1975). The notion of outcome expectancy originates from the ExpectancyValue Model (Atkinson, 1957), which in turn forms the theoretical basis for SCT. Through directing our subjective assessment of whether or not a given behavior produces desired or unwanted outcomes (Bandura, 1986), outcome expectancy is deterministic of one's attitude toward the behavior. In the context of digital learning environments, Collaborative Attitude (CA) signifies an individual's positive and negative feelings about engaging in group work, which ultimately will result in learners' approval or disapproval of such behavior. Because prior research on e-learning has demonstrated that usage intention toward collaborative technologies are strongly correlated with positive attitudes toward such technologies (Park, 2009), we hypothesize that:

Hypothesis 3: An individual's collaborative attitude is related to their intention to engage in group work.

Negative Collaborative Experience (NCE), conceived in this study as the degree to which an individual has experienced obstacles in group work based on previous experience(s), is vital in collaborative settings and even more so within digital learning environments where participants are dispersed globally. According to SCT, individuals are inclined to revert to previous experiences when deciding on future actions, forming generalized mental models on the basis of past encounters (Bandura, 1986). While such mental models offer useful heuristics for decision making, they can be equally detrimental by fixating individuals on negative stereotypes. Overgeneralization from previous negative experiences can mislead individuals into rejecting beneficial behavior, a phenomenon termed as cognitive distortion (Dawes, 1964). 
Indeed, prior research has illustrated that learners may dislike group work due to NCE. Such negative experiences can be magnified in online learning environments due to the anonymous and distant nature of group work in such online environments (Ashcraft \& Treadwell, 2007; Smith et al., 2011). Particularly, past studies have identified social loafing (Latané, Williams, \& Harkins, 1979; Turel \& Zhang, 2011) as well as perceived lack of commitment, group coordination, time, and trust as pervasive challenges confronting individuals in both face-to-face and online collaborative settings (Razmerita \& Kirchner, 2015). As a consequence of previous negative experiences, learners may resist collaborative approaches to distance learning (Hillyard, Gillespie, \& Littig, 2010; Smith et al., 2011). Scholars have found that imposing group work will cause learners to view such requirements as either restraints on their self-determination (de George-Walker \& Keeffe, 2010), undeserved opportunities for free-riders and underachievers to unfairly benefit from the contribution by others, or just plain time-consuming. Consequently, NCE might affect learners' confidence in group work even if they feel able to function efficaciously in groups, thereby attenuating the positive relationship between collaborative process efficacy and collaborative outcome expectancy. In the same vein, NCE is likely to attenuate the positive impact of communal influence on communal support expectancy because it challenges learners' belief that group work is an expected behavior among their peers.

In light of the adverse impact of previous negative experiences on individuals' collaborative disposition, we therefore hypothesize that NCE will attenuate the relationships between collaborative process efficacy and collaborative outcome expectancy as well as between communal influence and communal support expectancy (see Figure 1):

Hypothesis 4a: An individual's negative collaborative experiences will attenuate the effect of collaborative process efficacy on collaborative outcome expectancy.

Hypothesis 4b: An individual's negative collaborative experiences will attenuate the effect of communal influence on communal support expectancy.

Generally technological experience can be defined as "an opportunity to use a target technology and it is typically operationalized as the passage of time from the initial usage of technology by an individual" (Venkatesh, Thong, \& Xu, 2012:161). Past studies have demonstrated how previous experiences with Information Technology (IT) can positively influence individuals' attitudes toward future technology usage (Bhattacherjee \& Premkumar, 2004), especially in the domain of e-learning (Bull Schaefer \& Erskine, 2012; Chu \& Chen, 2016; Clark \& Gibb, 2006; Park, 2009; Siragusa \& Dixon, 2009). 
Venkatesh et al. (2014), through conducting a comprehensive review of the extant literature, found that individuals' learning experiences are dependent, among other things, on their prior knowledge of IT and their perceptions of the benefits to be gained from technology usage. Much as negative experiences with group work can culminate in unfavorable attitudes toward collaboration, we postulate that the opposite holds true for being more experienced with collaborative technology. Because IT-mediated communication constitutes the focal point of contact among learners in digital learning environments (Venkatesh et al., 2014), it is natural for learners' attitudes toward collaborative action to be shaped by their experiences in harnessing collaborative technologies.

In other words, Collaborative Technology Experience (CTE), which we defined as the degree to which an individual possesses previous experience with utilizing collaborative technology for group work, is likely to strengthen learners' beliefs about their ability to leverage communal resources for achieving desirable outcomes. We thus hypothesize that CTE will reinforce the effects of communal support expectancy and collaborative outcome expectancy on collaborative attitudes (see Figure 1):

Hypothesis 5a: An individual's collaborative technology experience will reinforce the effect of collaborative outcome expectancy on collaborative attitude.

Hypothesis 5b: An individual's collaborative technology experience will reinforce the effect of communal support expectancy on collaborative attitude.

\subsection{Modeling Behavioral Consequences of Collaborative Intention}

The second model bridges collaborative intention with behavior; it refers to the outcomes of collaborative behavior (here labeled "group work engagement"). The first step of this model is a simple test of how collaborative intentions predict collaborative behavior. Following the tenets of the TPB (Ajzen, 2011) presented earlier in section 2.3, we assume that individuals who intend to join group work are also more likely to actually engage in collaborative behavior (see Figure 2). We therefore hypothesize that:

Hypothesis 6: An individual's collaborative intention is related to their engagement in group work.

Drawing on Vygotsky's theory of proximal development (Vygotsky, 1978) we propose that collaborative behavior is related to positive learning outcomes as students learn from their peers (Chaiklin, 2003; Hogan \& Tudge, 1999). The assumption of proximal development in online contexts (Sharda et al., 2004) is backed by previous work that has found that collaborative work is important in supporting a growth in group confidence, trust and cohesion, resulting in positive outcomes of collaborative online work (MacDonald, 2003). Moreover, 
research shows that collaborative work leads to better test scores than individual work (Cortright, Collins, Rodenbaugh, \& DiCarlo, 2009). We therefore hypothesize that:

Hypothesis 7: An individual's group work engagement is related to their learning experience.

So far, little research has been carried out on the link between collaborative work in an OLE or MOOC context and the retention of participants, which is unfortunate given that high dropout rates constitute one of the major challenges faced by MOOCs (Koller, Ng, Do, \& Chen, 2013). The little existing research suggests that learner-learner interaction in MOOC courses is limited and heavily dependent on a few highly-engaged learners (Tawfik et al., 2017). The lack of empirical studies in an OLE context is surprising given that the positive effect of collaborative interaction on school drop-out rates has been well established previously (Dennison, 2000). In general, social-interactive engagement has a significant impact on the motivation of participants and their retention rate in MOOCs (Wang, Guo, He, \& Wu, 2019). Social interactive engagement is associated with active participation in discussions, comments, likes or sharing of resources online. Moreover, higher participation rates have been advanced as a predictor of better learning outcomes (Fredricks et al., 2004). We therefore hypothesize that:

Hypothesis 8a: An individual's group work engagement is related to higher retention rates.

Hypothesis $8 \boldsymbol{b}$ : Higher retention rates are related to a positive learning experience.

A final element of our second model refers to idea novelty as outcome of the collaborative process. Creativity is defined as the "production of novel and useful ideas by an individual or a small group of individuals working together" (Amabile, 1988). In line with this definition, we define idea novelty as the degree to which the generated collaborative outcome (e.g. course assignment solution) is perceived to be new or creative by the group members.

Creativity research has documented that generation of novel ideas is enhanced by collaborative efforts (Garfield et al., 2001; Paulus \& Nijstad, 2003). The creative process can be divided into four cognitive and behavioral sub-processes: synthesis, engagement, interaction and creation (Slavich \& Svejenova, 2016). We adapt these creative processes to online collaboration. Synthesis is a cognitive processes that connects separate elements (thoughts, intuition or ideas) generated through group work in a whole or a solution. Engagement and interactions are behavioral and relational processes that reveal the role of groups in creative processes. Creation is a process of bringing ideas into a collaborative outcome. Creativity can be seen as a feature of the outcome (a solution or a product) and is often subjectively assessed. We therefore hypothesize that: 
Hypothesis 9a: An individual's group work engagement is related to idea novelty.

Hypothesis 9b: The idea novelty is related to a positive learning experience.

\section{METHODOLOGY}

Hypothesized relationships in our research model (see Figures 1 and 2) were validated via a survey questionnaire administered at the onset of the course $\left(t_{1}\right)$ and at the end of the course $\left(t_{2}\right)$. Respondents were recruited from the student population enrolled in a twelve-week MOOC entitled 'Social Entrepreneurship' that was offered on the Coursera site (for more on the course see Hockerts, 2018). The course combines case studies with group work and video recordings of lectures. According to the course learning objectives, students are expected to form groups to co-create innovative ideas for launching a so called "social enterprise" (Kannampuzha \& Hockerts, 2019). The final grade is determined by a business plan that can be produced in groups or individually. The business plan was assessed through peer review and resulted in either a 'fail', 'pass', or 'pass with distinction' grade. There were no prerequisites imposed for enrolling in the course.

At the beginning of the course, students were instructed to form self-organized groups by leveraging on the online forum to locate peers interested in the same topic. Once formed, groups were instructed to: (1) define a social problem worthy of investigation; (2) devise a way to address the problem, and; (3) compose a business plan. Although group work was strongly encouraged, students were permitted to work on their own. All in all, 250 groups were formed and on average, groups typically comprised approximately four to eight students.

Out of 28,967 who signed up for the course in April 2015, 17,385 ( 60.0\%) students started the course. A total of 2,517 completed responses were obtained for the initial survey in $t_{1}$, translating into a response rate of $14.5 \%$. Because students' commitment in MOOCs is lower than in traditional classrooms, such a response rate is not unusual and conforms to those of past studies on MOOCs (Shapiro et al., 2017; Zhenghao, Alcorn, Christensen, \& Eriksson, 2015). Although participants who completed the course will be awarded a participation diploma, the primary motivation for students' enrollment appears to be rooted in their desire to be involved in actually launching a social enterprise. Results indicate that about $78.9 \%$ of respondents anticipate that they will be involved in launching a social enterprise in the next five years, with a further $18.8 \%$ being unsure. Out of 17,385 students who started the course, only 1,050 $(\sim 6.0 \%)$ remained active till the end. Toward the end of the course, a course evaluation survey $\left(t_{2}\right)$ was administered, which contained questions pertaining to group work engagement, idea novelty, retention, and learning experience. The course evaluation survey was disseminated to 
all 2,517 students who had responded to the initial survey. Inevitably, completed responses obtained for the course evaluation survey is considerably smaller [i.e., $N=143$ ] than that for the initial survey, because the former was administered after a time lapse of 12 weeks.

Multiple-item scales were employed to measure the latent variables. Each item assumes the form of a 5-point Likert-scale ranging from 1 - 'Strongly Disagree' to 5 - 'Strongly Agree'. Measurement items for the latent constructs in our research model were either adapted from the work of Razmerita and Kirchner (2015) or developed in accordance with standard psychometric procedures. Specifically, negative collaborative experience was measured as the extent to which an individual had previously experienced various challenges related to group work, including: coordination troubles and distrust (Sonnenwald \& Pierce, 2000), as well as social loafing (Earley, 1989; Liden, Wayne, Jaworski, \& Bennett, 2004). Appendix A summarizes the list of measurement items employed for data collection across both surveys.

Partial Least Squares (PLS) analysis was employed to validate both the measurement and structural properties of our research model. PLS analysis is preferred because it verifies the psychometric properties of the measurement items (i.e., measurement model) while simultaneously analyzing the direction and strength of each hypothesized relationship (i.e., structural model). Furthermore, it incorporates both mediators and moderators into one joint model for data analysis.

\subsection{Sampling}

For our sample of 2,517 respondents in $t_{1}, 54.7 \%$ were females with ages ranging from 14 to 73, averaging 35 years old (see Table 2). A majority of respondents had college education or higher $(87 \%)$. Descriptive statistics further indicate that $76.5 \%$ of respondents already possessed extensive experience with group work and $67.7 \%$ had in the past been exposed to ecollaboration tools, which included social networking technologies (e.g., Google Hangout, Facebook, and Podio). In terms of nationality, the sample comprised respondents from 120 countries with the five most represented nationalities being the United States (15.7\%), India (10.5\%), Mexico (4.3\%), Brazil (4.2\%), and Spain (2.8\%). Likewise, for our sample of 143 respondents in $t_{2}, 58 \%$ were females with ages ranging from 12 to 59 , averaging 30 years old (see Table 2). The majority of respondents also possessed college education or higher (94\%).

Table 2 gives a breakdown of the demographic distribution of respondents for both surveys. Paired $t$-tests comparing the demographic distribution of respondents from the initial survey $\left(t_{1}\right)$ with those from the course evaluation survey $\left(t_{2}\right)$ reveal that both samples are comparable (see Table 2 for paired $t$-test analytical results). 
--- Insert Table 2 here: Descriptive Statistics for Survey Respondents ---

\subsection{Test of Measurement Model}

Because cross-sectional surveys may be plagued by common method bias, we compared model fit indices between our original measurement model and a singular construct model (see Table 3) for both $t_{1}$ and $t_{2}$. As can be inferred from Table 3, the model fit indices for our original measurement model in both $t_{1}$ and $t_{2}$ is, by far, superior to that of the singular construct model, implying that common method bias is unlikely to be a threat to this study.

\section{--- Insert Table 3 here: Test of Common Method Bias ---}

Additionally, adhering to standard practice (according to Podsakoff, MacKenzie, Lee, \& Podsakoff, 2003), we controlled for the effects of an unmeasured latent methods factor during data analysis ${ }^{1}$. Taken together, the above-mentioned procedures ensure that common method bias is unlikely to threaten the validity of our findings. Next, we estimated the internal consistency as well as the convergent and discriminant validity of the measurement items included in our survey instrument for both $t_{1}$ and $t_{2}$. Because reflective items capture the impact of the construct under scrutiny, internal consistency can be assessed through standard estimates of Cronbach's alpha, composite reliability, and Average Variance Extracted (AVE). As shown in Table 4, with the exception of communal influence which attained a Cronbach's alpha value of 0.60 , all latent constructs exceed recommended thresholds for $t_{1}$. As contended by Briggs and Cheek (1986), Cronbach's alpha registered a low value whenever there were fewer than 10 measurement items for a given construct and indicated that it would be more informative to calculate inter-item correlations under such circumstances. Consistent with Briggs and Cheek's (1986) prescription, computed inter-item correlation values for communal influence fell within the optimal range of 0.2 to 0.4 . Coupled with the factorial loadings of measurement items being higher than 0.70 on their respective latent constructs (see Appendix A), we can affirm the reliability of the latent constructs for $t_{1}$.

\footnotetext{
${ }^{1}$ According to the analytical procedures outlined by Podsakoff et al. (2003) measurement items are allowed to load on their respective theoretical constructs depicted in Figures 1 and 2, as well as on a latent common methods factor. Through inspecting the significance of the structural model parameters both with and without the latent common methods factor, we can partition the variance of responses to a given measure into three components: (a) trait, (b) method, and; (c) random error.
} 
--- Table 4: Inter-Construct Correlation Matrix for Model $t_{1}$---

To ascertain discriminant validity, the square root of the AVE for each construct was compared against its correlations with other constructs (Fornell \& Larcker, 1981). For the criterion of discriminant validity to hold, the square root of the AVE for each construct should be greater than its correlations with any other construct. Based on the inter-construct correlation matrix generated from PLS (see Table 4), all constructs in $t_{1}$ displayed sufficient discriminant validity. Employing the same criteria, we can equally deduce that all constructs in $t_{2}$ exhibit convergent and discriminant validity (see Table 5).

--- Table 5: Inter-Construct Correlation Matrix for Model $t_{2}$---

\subsection{Test of Structural Model on Antecedents of Collaborative Intention ( $\left.t_{1}\right)$}

Results from the analysis of our structural model on the antecedents of collaborative intention, including path coefficients and their statistical significance, are illustrated in Figure 3. Standard errors were computed via a bootstrapping procedure with 500 re-samples.

--- Insert Figure 3 here: Results of Structural Model Analysis $\left(t_{1}\right)$---

Before assessing the path coefficients in our structural model, we first assessed its model fit to ascertain whether our structural model accurately represented the underlying pattern in our data (Hooper, Coughlan, \& Mullen, 2008). The normalized chi-squared index (i.e., $\chi^{2 / \mathrm{df}}$ ) of the structural model $\left(\chi^{2} / \mathrm{df}=751.95 / 2,438=0.308\right)$ is considerably below the threshold of 5.0 recommended in prior research (Chen \& Chen, 2010; Hooper et al., 2008). Likewise, the Standardized Root Mean Square Residual (SRMR) index of our structural model is below the recommended upper threshold of 0.1 (Kline, 2015) and the recommended criteria of 0.8 for Normed Fit Index (NFI) has been surpassed by our structural model (Hooper et al., 2008). Taken together, it indicates that our structural model exhibits acceptable model fit. Additionally, we compare our research model against a baseline model whereby we model all seven antecedent constructs (i.e., collaborative process efficacy, collaborative outcome expectancy, communal influence, communal support, collaborative attitude, negative collaborative experience, and collaborative technology experience) as having a direct effect on collaborative intention (see Figure 5). As can be inferred from the superior fit indices exhibited by our research model, the hypothesized relationships among the eight focal constructs constitute a more accurate reflection of the empirical observations. 
From our data analysis, nearly all hypothesized relationships were substantiated by the empirical evidence. As hypothesized, collaborative process efficacy and communal influence exert positive and significant effects on collaborative outcome expectancy $(\beta=0.483 ; p<.001)$ and communal support expectancy $(\beta=0.301 ; p<.001)$ respectively, explaining $23.8 \%$ and $11.4 \%$ of the variance in the two constructs. Hypotheses 1a and $2 \mathrm{a}$ are therefore corroborated.

In turn, collaborative outcome expectancy $(\beta=0.367 ; p<.001)$ and communal support expectancy $(\beta=0.267 ; p<.001)$ exhibit a significant and positive impact on collaborative attitude, explaining $32.6 \%$ of the variance in the latter. Hypotheses $1 \mathrm{~b}$ and $2 \mathrm{~b}$ are thus substantiated. Finally, collaborative attitude is found to affect collaborative intention positively ( $\beta=0.454 ; p<.001$ ), explaining $20.6 \%$ of the variance and lending support to Hypothesis 3 .

As for the moderators, negative collaborative experience attenuates the positive effect of collaborative process efficacy on collaborative outcome expectancy $(\beta=-0.080 ; p<.01)$ as predicted. However, the reinforcement of the relationship between communal influence and communal support expectancy $(\beta=0.083 ; p<.01)$ runs contrary to our expectations. In other words, the more negative group experience respondents possess, the stronger is the relationship between communal influence and communal support expectancy. One plausible explanation for this unexpected result might be that respondents who have negative group experience, could better appreciate the value of communal support in response to problems encountered in group work. Conversely, respondents with little negative collaborative experience would be less appreciative of a supportive environment, simply because they did not require support from their peers. In conclusion, hypothesis $4 \mathrm{a}$ is supported but not Hypothesis $4 \mathrm{~b}$.

Similarly, even though collaborative technology experience reinforces the positive impact of collaborative outcome expectancy on collaborative attitude $(\beta=0.080 ; p<.05)$ as postulated, it does not influence the relationship between communal support expectancy and collaborative attitude $(\beta=-0.060 ; p>.05)$. This lends credibility to Hypothesis 5 a, but not Hypothesis 5b. In other words, while we can confirm that collaborative technology experience will reinforce the relationship between collaborative outcome expectancy and collaborative attitude, we did not find that collaborative technology experience reinforced the relationship between communal support expectancy and collaborative attitude. This indicates the possibility that respondents view technology as a means for harnessing communal outcome efficacy rather than facilitating communal support activities. Interaction plots (with 1 standard deviation range) for the moderating effects of negative collaborative experience and collaborative technology experience are shown in Figure 4. 


\subsection{Test of Structural Model on Behavioral Consequences of Collaborative Intention} $\left(t_{2}\right)$

In a second step, we conducted additional analysis to ascertain if a priori intentions culminate in one's actual collaborative behavior by modeling collaborative intention as an antecedent affecting individuals' engagement in group work, which in turn influences learning experience through course retention and idea novelty (see Figure 2). The analysis is based on self-reported reflective measures from the course evaluation survey administered in $t_{2}$ (see Appendix A). For each respondent, the corresponding data on collaborative intention in $t_{1}$ was matched.

Building on prior research, we surmised that group work engagement would reinforce students' learning experience and also retention (Alavi \& Gallupe, 2003; Johnson \& Johnson, 1987). Furthermore, due to the abundance of empirical evidence that alludes to the pivotal role of collective brainstorming and divergent thinking in bolstering creativity, we anticipated that group work engagement would also foster greater idea novelty (Cardellini, 2006; Paulus \& Nijstad, 2003).

Based on the 143 answers of the respondents that completed both surveys ( $\mathrm{t} 1$ and $\mathrm{t} 2$ ), approximately $21 \%$ never joined a group, $9 \%$ were passive users in groups, $22 \%$ slightly active in group work, $29 \%$ active and $18 \%$ assumed leadership role in the groups. Results from the analysis of the structural model connecting collaborative intentions and group work engagement to learning outcomes (i.e. learning experience, retention, and idea novelty), including path coefficients and their statistical significance, are illustrated in Figure 5. Standard errors were computed via a bootstrapping procedure with 500 re-samples. Again, comparisons between our research model and a baseline model - in which collaborative intention, group work engagement, course retention, and idea novelty were modeled as having a direct effect on learning experience - indicates that our research model is a better match with empirical observations.

\section{--- Insert Figure 5 here: Results of Structural Model Analysis $\left(t_{2}\right)$---}

As anticipated, collaborative intention exerts a positive and significant impact on engagement in group work $(\beta=0.230 ; p<.01)$, explaining $5.3 \%$ of variance in the latter, confirming hypothesis 6 . Conversely, and contrary to our hypothesis 7 , engagement in group work does not affect learning experience $(\beta=-0.105 ; p>.05)$. However, the two indirect mediator effects were confirmed. In line with hypothesis 8a, engagement in group work 
positively influences course retention $(\beta=0.450 ; p<.001)$ explaining $20.3 \%$ of variance in retention. In the same vein, engagement in group work also exerts a statistically significant positive effect on idea novelty $(\beta=0.237 ; p<.01)$, explaining $5.6 \%$ of variance as suggested in hypothesis 9a. In turn, course retention $(\beta=0.253 ; p<.01)$ and idea novelty $(\beta=0.311 ; p<$ .001 ) enhance learning experience, explaining $16.8 \%$ of variance in the latter. Hypotheses $8 \mathrm{~b}$ and $9 \mathrm{~b}$ are thus corroborated.

In light of the preceding analytical results, we can conclude that collaborative intention induces one to subsequently engage in group work, thereby contributing to a higher course retention rate and increased idea novelty generated through collaboration. In turn, higher retention rates and increased idea novelty drive students' learning experience with MOOCs. It is further inferable from the non-significant relationship between group work engagement and learning experience that collaborative behavior does not impact learning experience directly and is dependent on the enticement of course retention and idea novelty to bring about enhanced learning experience. Taken together, our behavioral model analysis (presented in Figure 5) lends credibility to our proposition that group work engagement yields substantive merits for digital learning environments like MOOCs.

\section{DISCUSSION}

So far little is known about how to support collaboration in a MOOC environment (Wen et al., 2015). A better understanding of which factors affect group work and the intention to collaborate will support learning in online environments (and in particular in MOOCs) which will increase the intention to stay in the course and thus improve learning outcomes (Zhang et al., 2016). To our knowledge, this study is the first to proffer an integrative view of the reasons underlying why learners may refrain from engaging in group work owing to both individual and communal considerations in digital learning environments. To a large extent, this study complements extant literature by deriving and validating salient drivers of collaborative intentions in digital learning environments. Furthermore, it is one of the first studies to connect collaborative intention (pre-intention model-Figure 3) with behavior (post-intention model Figure 5). Findings from our study not only contribute to literature on collaborative learning and group work in online environments, but also paint a holistic picture of the determinants of collaborative intentions for online courses participants. In this way, our study bears important implications for both theory and practice. 
Research on the future of online learning environments involves a number of critical issues (Oncu \& Cakir, 2011) among which: 1) enhancing learner engagement and collaboration, 2) promoting effective facilitation strategies to foster learner engagement, 3) developing assessment techniques 4) designing faculty development programs. Our paper contributes to the research call on the first and second topic of learner engagement by unravelling factors that contribute to engagement in collaboration and the impact of group work on learning experience.

\subsection{Implications for Theory}

Responding to scholarly calls for further research into individual and communal determinants of learners' intention to engage in group work (Dillenbourg, 1999; Stahl et al., 2006), we advance a research model of collaborative intention that draws on cognitive and collective interaction theories. In line with Theory of Planned Behaviour (TPB) and previous research, our theoretical model also synthesizes factors that influence the attitude toward collaboration. TPB does not take into account expectations of collective interactions. Unlike TPB we include both individual and communal contextual factors that contribute to a more positive or negative attitude toward collaboration. While TPB and social exchange theory theorize people's behavior as rational, social cognitive theory and social interaction theory cover an affective and social-interactive dimension of collaboration.

Our model argues for a combined relationship between individual factors (cognitive beliefs, technology experience, self-efficacy) and communal factors (social norms or support) that influence the outcome expectancy, attitude and intention to engage in group work. The model differentiates between individual learners' perceived ability to achieve desired outcomes from group work (i.e., relationship between collaborative process efficacy and collaborative outcome expectancy) as well as the accessibility of communal support to aid them in achieving targeted outcomes (i.e., relationship between communal influence and communal support expectancy).

Furthermore, we posit that both collaborative outcome expectancy and communal support expectancy dictate learners' collaborative attitudes and intentions. We also distinguish between negative collaborative experience and collaborative technology experience as moderators that should be taken into account when deciphering the factors affecting learners' intentions to collaborate in digital learning environments. In line with Bandura's theoretical argument, there is a triadic reciprocal relationship between internal personal factors (cognitive and affective), the external environment (in our case the MOOC as an online learning 
environment, collective support and the associated social norms) and intention as antecedent of behavior. Bandura theorizes the conditional relationship between efficacy beliefs, behavior and outcome expectancies. The efficacy beliefs vary in strength, level and generality. Efficacy beliefs can lead to negative outcome such as resignation or apathy or to positive outcomes expectancy like productive engagement or satisfaction (Bandura, 1997). In a similar vein, we argue that Communal Influence and Collaborative Process Efficacy (CPE) can lead to positive collaborative engagement and satisfaction or disengagement from group work or even dropout from the group work or from the course.

The post intention model tests the effect of collaborative behavior on collaboration outcomes. The post-intention model builds a conceptual model that links collaborative intention with behavior (group work engagement), retention, creativity and learning experience. Our model has been tested empirically. Engagement in collaboration leads to a perceived creative process and production of novel ideas through group work which in turn leads to a positive learning experience. Furthermore, group work engagement has also a significant impact on the retention rate of participants which is related to a better learning experience. It uniquely contributes to research on online collaboration, creativity, retention, MOOCs and online learning environments theory. Our findings are congruent with previous research pointing to a positive association between group work and virtual collaboration outcomes. Collaboration encourages social interaction and information exchanges and provides opportunity for a more interactive learning (Taras et al., 2013).

By examining not just group work intentions in MOOCs but also actual collaborative behavior and its positive outcomes this study goes well beyond what most extant research has done.

We hope that this contribution will lead to even more research into online collaboration and collaborative behavior in MOOCs, which we contend is an essential research need in different types of OLEs.

\subsection{Implications for Practice}

Apart from formal instruction, online collaboration using group work is an attempt to introduce the informal and interactive elements of classroom teaching in an online environment. Currently most MOOC courses and MOOC platforms' design instill expectations among their participants that individual work is actually the norm. In terms of the specific implication for practice, our research suggests that both MOOC designers and teachers will 
have to spend more resources on priming the students that collaboration is beneficial and should be the prevailing norm in the course, which is currently not the case for most of the MOOCs. The teachers should aim to create a positive learning environment, with a sense of purpose for collaboration and membership. In a positive learning environment, an individual feels safe in terms of receiving feedback, collaborating, sharing ideas, asking for advice or coaching each other. Collaboration through group work can offer a medium for individuals to share knowledge, experience and skills and thus increase the chances for novel idea generation.

Our study accentuates distinct individual and communal (social) factors that are deterministic of learners' decision to engage in online collaboration. An in-depth appreciation of these factors is crucial for prescribing pedagogical interventions aimed at increasing engagement and interaction while mitigating previous negative experiences. Collaborative intentions (or their absence) impact how individuals act once they are faced with actual group work requests in an online environment like MOOCs. As for in-course interventions, our research suggests that teachers should aim to improve collaborative process efficacy (perceived group work skills) and communal influence with the aim of improving attitudes toward group work prior to starting the course. Extant research on attempts to increase self-efficacy of computer users demonstrates, for example, the effect different training methods can have on participants (Gist, Schwoerer, \& Rosen, 1989). In the context of MOOCs this could be achieved by including an introductory session about group work at the outset of the MOOC to make participants aware of importance of group work and successful group work practices in collaborative online environments. Teachers should highlight that group work is both expected and relevant for learning in this MOOC community, thus strengthening participant beliefs about the norms in online environments.

Moreover, in order to increase communal norms about group work, MOOC teachers should encourage group members to agree on an explicit group work contract or "team charter" (Hillier \& Dunn-Jensen, 2012) to be discussed among group members, containing rules for successful collaboration (e.g. coordination, how often they communicate and which tools to use, group work outcome expectations). Group members should be encouraged to discuss their previous experiences, including how they dealt with challenges. Clear rules in form of a group contract can help to mitigate previous negative collaborative experience and thus increase both collaborative outcome expectancy and support expectancy. Moreover, teachers should also explore the use of verbal self-guidance trainings as a means of improving collaborative process efficacy (Brown, 2003). 
Peer assessment of group members could be included in the course as a way to mitigate negative collaborative experience (e.g. social loafing) which could in turn impact communal norms. In order to strengthen communal norms further, the skills and roles of each member should be discussed, and which expectation and aim each participant has. A forum in the MOOC can be opened where people can introduce themselves, their skills and group work expectations and find like-minded contributors for the group work.

From a technical point of view, MOOC development needs to move beyond discussion boards as the primary place for group work and collaboration. MOOC platforms may gain from drawing on gamification strategies to support active engagement in group work and other collaborative activities (e.g. badges for successful collaboration). Gamification can be used to foster participation in a learning community at group level. Gamification mechanisms calculate scores or give rewards based on the participants' interaction and contributions to the group. Such scores and rewards influence motivation and engagement and downgrade free riders (Moccozet, Tardy, Opprecht, \& Leonard, 2013). Other tools that might be used to motivate group work engagement include conversational agents as a means of creating awareness or changing user behavior in relation to a specific goal (e.g. knowledge sharing, collaboration) (Nabeth, Razmerita, Angehrn, \& Roda, 2005).

MOOC designers and instructors have to keep a vigilant eye on the "emotional contagion" of negative communal influence (Schaefer \& Palanski, 2014) because such influence is often impossible to reverse once it becomes entrenched. This is particularly pertinent for digital learning platforms such as Coursera where participants tend to enroll in multiple courses. Negative experiences from one course may spill over to other courses as time passes (Hillyard et al., 2010; Taras et al., 2013) via "electronic word-of-mouth communication" (Pedersen, Razmerita, \& Colleoni, 2014: 112).

The results from our behavioral model analysis indicate that group work engagement may be particularly relevant for courses in which participants aim to generate novel ideas (such as in the case of a MOOC in which students are expected to write a business plan). Possibly group work engagement is somewhat less relevant for courses that involve rote learning such as in the case of a MOOC merely teaching the mechanics of say a statistical method.

Last but not least, our study is relevant to the growing number of educators involved in the design and facilitation of collaboration in MOOCs or other online or blended learning environments. Focusing only on content quality and hoping that group work will happen automatically is probably going to lead to suboptimal pedagogical results. 


\subsection{Limitations and Future Research}

There are caveats that may limit the generalizability of our findings. First, our findings are derived from empirical evidence gathered from a single MOOC course. Consequently, we cannot account for plausible disparities between participants in business courses and those enrolled in courses for other disciplines which may exhibit distinct group dynamics. Incidentally, even though research on MOOCs is gaining momentum, there is still a paucity of studies that delve into the suitability of online pedagogies for specific topics. Pursuing such a line of work would be invaluable in shedding light on the impact of potential idiosyncrasies across various academic disciplines on learners' collaborative intentions in digital learning environments.

Future research should strive to systematically tease out the impact of various pedagogical activities on each of the individual and communal factors embodied in our research model. For instance, interventions targeting collaborative outcome expectancy could be measured through the use of analytics associated with collaborating tools used by groups (e.g. open innovation platforms and workflow planning systems). Collaborative support expectancy might be more susceptible to interventions that bridge social chasms among group members (e.g. linking Instagram or Facebook accounts of group members, photo streams, video chat features, and regular 360-degree feedback systems).

Our collaborative intention model focuses on group work intentions and their antecedents. While intentions to collaborate are not perfect predictors of future behavior (for example contingencies such as a sickness or urgent tasks at work may cause people not to act on their intention to join group work), they nonetheless form the basis for future actions (Armitage \& Conner, 2001). This is in line with the findings from the post-intention model analysis (see Figure 5), based on data collected at the end of the course, where we show that intentions do indeed predict actual behavior (group work engagement).

Considering the results of our behavioral analysis, future research is also called upon to better understand the effects of group work engagement. Our findings suggest that group work engagement may very well be a good mechanism to increase course retention. In particular it will be important to establish causality beyond the observed correlation. Thus, while we propose that it is group work that causes retention, it would be prudent to test the opposite hypothesis, namely that it is retention rate that drives group work engagement.

We do, however, have to point out, that according to the data presented in this study, the connection between collaborative intentions and actual MOOC group work behavior is rather 
tenuous, given that the variance explained of only $5 \%$ is rather low. This indicates that over the three-month period of the MOOC course other factors have been relevant that so far remain unobserved. Such results are not unexpected given that prior research has demonstrated that the link between self-reported intentions and later actual behavior tends to be weak (Wood et al., 2016). This points at a need for future studies to more directly link the antecedents of our pre-intention model with eventual behavioral outcomes.

It could be interesting for future research to draw on the work of Gollwitzer and Brandstätter (1997) who differentiate between goal intentions (I intend to achieve a goal) and implementation intentions (I intend to perform goal directed behavior). Such research might be well placed to better understand which implementation intentions are most likely to result in actual group work behavior and its associated outcomes.

A subsequent route of investigation could possibly correlate the level of engagement or type of activity of participants in group work with collaborative outcomes and learning experience. This in turn would allow us to study different classifications of different types of participant behaviors according to levels of activity, type of activity or number of contributions (Razmerita, 2011). Such behaviors in the context of MOOCs could be defined as: very active, active, visitor or inactive participant. As the research on MOOC group work matures, it will also be increasingly important that future efforts provide a more fine-grained understanding of the different subtypes of participants' behavior, the collaborative outcomes and their respective antecedents.

In addition to quantitative analyses, such questions may also be addressed using qualitative research techniques, which would allow researchers to collect rich inductive descriptive and explanatory empirical material of student behavior in an OLE context. Methods such as Pentland's (1999) building of process theory through narratives could be highly appropriate.

Further research is still required to establish the extent to which collaboration and group work influence learners' performance in digital learning environments. Such studies should test whether the inclusion of group work in MOOCs does lead to discernible improvements in learners' motivation, satisfaction, and actual learning experience. Such studies may be well conducted using an inductive qualitative method. New qualitative research methods such as netnography could be particularly useful in the context of online MOOC courses.

Even though we have attempted to eliminate threats of common method bias in the study by demonstrating that our original measurement model with eight focal constructs produces a better fit with the data as opposed to a singular construct model and conducting exploratory 
analyses to ascertain the temporal impact of collaborative intention on focal learning outcomes, we acknowledge that common method bias could still pose a challenge to the validity of our findings. Future research should therefore re-assess our research model via a multi-trait, multimethod approach to certify that our findings are not biased by relying on a single method of data collection.

Finally, we call upon future scholars to study in more depth the effect group work engagement has on innovation and idea novelty. We assume that it is the global diversity of MOOC participants that drives novel idea generation, creativity and potential innovation. 


\section{REFERENCES}

Ajzen, I. 1985. From intentions to actions: A theory of planned behavior. In J. Kuhl \& J. Beckmann (Eds.), Action Control: 11-39. Springer.

Ajzen, I. 1991. The theory of planned behavior. (P. A. M. Lange, A. W. Kruglanski, \& E. T. Higgins, Eds.)Organizational Behavior and Human Decision Processes, 50(2): 179211.

Ajzen, I. 2002. Perceived Behavioral Control, Self-Efficacy, Locus of Control, and the Theory of Planned Behavior. Journal of Applied Social Psychology, 32(4): 665-683.

Ajzen, I. 2011. The theory of planned behaviour: Reactions and reflections. Psychology and Health, 26(9): 113-1127.

Alavi, M., \& Gallupe, R. B. 2003. Using information technology in learning: Case studies in business and management education programs. Academy of Management Learning and Education, 2(2): 139-153.

Alraimi, K. M., Zo, H., \& Ciganek, A. P. 2015. Understanding the MOOCs continuance: The role of openness and reputation. Computers \& Education, 80: 28-38.

Amabile, T. M. 1988. A model of creativity and innovation in organizations. Research in Organizational Behavior, 10(1): 123-167.

Ames, C. 1992. Classrooms: Goals, Structures, and Student Motivation. Journal of Educational Psychology, 84(3): 261-271.

Andersen, R., \& Ponti, M. 2014. Participatory pedagogy in an open educational course: challenges and opportunities. Distance Education, 35(2): 234-249.

Arbaugh, J. B., Dearmond, S., \& Rau, B. L. 2013. New uses for existing tools? A call to study on-line management instruction and instructors. Academy of Management Learning and Education, 12(4): 635-655.

Armitage, C. J., \& Conner, M. 2001. Efficacy of the theory of planned behaviour: A metaanalytic review. British Journal of Social Psychology, 40(4): 471-499.

Ashcraft, D., \& Treadwell, T. 2007. The social psychology of online collaborative learning: The good, the bad, and the awkward. Computer-Supported Collaborative Learning: Best Practices and Principles for Instructors, 114-139.

Atkinson, J. W. 1957. Motivational determinants of risk-taking behavior. Psychological Review, 64(6): 359-372.

Bandura, A. 1971. Social learning theory. Social Learning Theory. New Jersey: PrenticeHall.

Bandura, A. 1977. Self-efficacy: toward a unifying theory of behavioral change. Psychological Review, 84(2): 191-215.

Bandura, A. 1986. Social foundations of thought and action: A social cognitive theory. Prentice-Hall series in social learning theory., vol. xiii.

Bandura, A. 1989. Human agency in social cognitive theory. American Psychologist, 44(9): $1175-1184$.

Bandura, A. 1991. Social cognitive theory of self-regulation. Organizational Behavior and Human Decision Processes, 50(2): 248-287. 
Bandura, A. 1997. Self-Efficacy. The Excercise of Control. New York, New York, USA: W.H. Freeman and Company.

Bandura, A. 2001. Social Cognitive Theory: An Agentic Perspective. Annu. Rev. Psychol., 52(December): 1-26.

Bandura, A. 2006. Toward a psychology of human agency. Perspectives on Psychological Science, 1: 164-180.

Bandura, A., \& Walters, R. H. 1963. Social learning and personality development. New York: Holt, Rinehart and Winston.

Barak, M., Watted, A., \& Haick, H. 2016. Motivation to learn in massive open online courses: Examining aspects of language and social engagement. Computers $\mathbb{\&}$ Education, 94: 49-60.

Barbera, F., Bernhard, F., Nacht, J., \& McCann, G. 2015. The Relevance of a Whole-Person Learning Approach to Family Business Education: Concepts, Evidence, and Implications. Academy of Management Learning \& Education, 14(3): 322-346.

Bayeck, R. Y., Hristova, A., Jablokow, K. W., \& Bonafini, F. 2018. Exploring the relevance of single-gender group formation: What we learn from a massive open online course (MOOC). British Journal of Educational Technology, 49(1): 88-100.

Beck, L., \& Ajzen, I. 1991. Predicting dishonest actions using the theory of planned behavior. Journal of Research in Personality, 25(3): 285-301.

Bhattacherjee, A., \& Premkumar, G. 2004. Understanding Changes in Belief and Attitude toward Information Technology Usage: A Theoretical Model and Longitudinal Test on JSTOR. MIS Quarterly, 28(2): 229-254.

Biggs, J., \& Tang, C. 2011. Teaching for Quality Learning at University (4th ed.). McGraw Hill. Berkshire, Open University Press.

Blasco, M. 2012. Aligning the Hidden Curriculum of Management Education With PRME: An Inquiry-Based Framework. Journal of Management Education, 36(3): 364-388.

Blasco, M., \& Tackney, C. 2013. "If it ain't broke, don't fix it": Internationalisation and the erosion of the positive hidden curriculum in Danish higher education. International Journal of Management in Education, 7(4): 341-359.

Blohm, I., Bretschneider, U., Leimeister, J. M., \& Krcmar, H. 2010. Does collaboration among participants lead to better ideas in IT-based idea competitions? An empirical investigation. Proceedings of the Annual Hawaii International Conference on System Sciences.

Brahimi, T., \& Sarirete, A. 2015. Learning outside the classroom through MOOCs. Computers in Human Behavior, 51(Part B): 604-609.

Branzei, O., \& Fredette, C. 2008. Effects of Newcomer Practicing on Cross-level Learning Distortions. Management Learning, 39(4): 393-412.

Briggs, S. R., \& Cheek, J. M. 1986. The role of factor analysis in the development and evaluation of personality scales. Journal of Personality, 54(1): 106-148.

Brown, T. C. 2003. The effect of verbal self-guidance training on collective efficacy and team performance. Personnel Psychology, 56(4): 935-964.

Bull Schaefer, R. A., \& Erskine, L. 2012. Virtual Team Meetings. Journal of Management Education, 36(6): 777-801. 
Cardellini, L. 2006. Fostering creative problem solving in chemistry through group work. Chemistry Education Research and Practice, 7(2): 131-140.

Chaiklin, S. 2003. The zone of proximal development in vygotsky's analysis of learning and instruction. In A. Kozulin, V. S. Ageyev, B. Gindis, \& S. M. Miller (Eds.), Vygotsky's Educational Theory in Cultural Context: 39-64. Cambridge University Press.

Chen, C.-C., Lee, C.-H., \& Hsiao, K.-L. 2018. Comparing the determinants of non-MOOC and MOOC continuance intention in Taiwan. Library Hi Tech, LHT-11-2016-0129.

Chen, C.-F., \& Chen, F.-S. 2010. Experience quality, perceived value, satisfaction and behavioral intentions for heritage tourists. Tourism Management, 31(1): 29-35.

Chen, Y.-H., \& Chen, P.-J. 2015. MOOC study group: Facilitation strategies, influential factors, and student perceived gains. Computers \& Education, 86: 55-70.

Chu, T.-H., \& Chen, Y.-Y. 2016. With Good We Become Good: Understanding e-learning adoption by theory of planned behavior and group influences. Computers $\&$ Education, 92-93: 37-52.

Cialdini, R. B., Reno, R. R., \& Kallgren, C. A. 1990. A focus theory of normative conduct: Recycling the concept of norms to reduce littering in public places. Journal of Personality and Social Psychology, 58(6): 1015-1026.

Clark, D. N., \& Gibb, J. L. 2006. Virtual Team Learning: An Introductory Study Team Exercise. Journal of Management Education, 30(6): 765-787.

Cohen, E. G., \& Lotan, R. A. 2014. Designing groupwork: Strategies for the heterogeneous classroom. Teachers College Press.

Cortright, R. N., Collins, H. L., Rodenbaugh, D. W., \& DiCarlo, S. E. 2009. Student Retention of Course Content is Improved by Collaborative-group Testing. Advances in Physiology Education, 27(3): 102-108.

Davis, F. D. 1989. Perceived Usefulness, Perceived Ease of Use, and User Acceptance of. MIS Quarterly, 13(3): 319-340.

Dawes, R. M. 1964. Cognitive distortion. Psychological Reports, 14(2): 443-459.

de George-Walker, L., \& Keeffe, M. 2010. Self-determined blended learning: A case study of blended learning design. Higher Education Research and Development, 29(1): 1-13.

Dennison, S. 2000. A win-win peer mentoring and tutoring program: A collaborative model. Journal of Primary Prevention, 20(3): 161-174.

Deutsch, M. 1949. A Theory of Co-operation and Competition. Human Relations, 2(2): 129152.

Deutsch, M. 1962. Cooperation and trust: Some theoretical notes. Nebraska Symposium on Motiviation, 275-320.

Dewey, J. 1938. Experience and Education. Education. New York: Touchstone.

Dillenbourg, Pierre. 1999. What do you mean by "collaborative learning"? In P. Dillenbourg (Ed.), Collaborative-learning: Cognitive and Computational Approaches: 1-19. Oxford: Elsevier.

Dixson, M. D. 2010. Creating effective student engagement in online courses: What do students find engaging? Journal of the Scholarship of Teaching \& Learning, 10(2): 113. 
Earley, P. C. 1989. Social loafing and collectivism: A comparison of the United States and the People's Republic of China. Administrative Science Quarterly, 565-581.

Ettington, D. R., \& Camp, R. R. 2002. Facilitating Transfer of Skills between Group Projects and Work Teams. Journal of Management Education, 26(4): 356-379.

Finn, J. D. 1993. School engagement \& students at risk. National Center for Education Statistics.

Fischer, G. 2014. Beyond hype and underestimation: identifying research challenges for the future of MOOCs. Distance Education, 35(2): 149-158.

Fishbein, M., \& Ajzen, I. 1975. Belief, Attitude, Intention, and Behavior, An Introduction to Theory and Research. Belief, Attitude, Intention, and Behavior, An Introduction to Theory and Research. Addison Wesley.

Fornell, C., \& Larcker, D. F. 1981. Evaluating Structural Equation Models with Unobservable Variables and Measurment Error. Journal of Marketing Research, 18(1): 39-50.

Fredricks, J. A., Blumenfeld, P. C., \& Paris, A. H. 2004. School Engagement: Potential of the Concept, State of the Evidence. Review of Educational Research, 74(1): 59-109.

Freire, P. 1970. The banking concept of education. Educational foundations: An anthology of critical readings: $99-111$.

Garfield, M. J., Taylor, N. J., Dennis, A. R., \& Satzinger, J. W. 2001. Modifying Paradigms Individual Differences, Creativity Techniques, and Exposure to Ideas in Group Idea Generation. Information Systems Research, 12(3): 322-333.

Garrison, R., \& Arbaugh, J. B. 2007. Researching the community of inquiry framework: Review, issues, and future directions. Internet and Higher Education, 10(3): 157-172.

Garvin, D. 2003. Making the Case: Professional Education for the World of Practice. Harvard Magazine, 106(1): 56-65.

Gherardi, S., Nicolini, D., \& Odella, F. 1998. Toward a social understanding of how people learn in organizations the notion of situated curriculum. Management Learning, 29(3): 273-297.

Giles, M., McClenahan, C., Cairns, E., \& Mallet, J. 2004. An application of the Theory of Planned Behaviour to blood donation: the importance of self-efficacy. Health Education Research, 19(4): 380-391.

Gillani, N., \& Eynon, R. 2014. Communication patterns in massively open online courses. Internet and Higher Education, 23: 18-26.

Gist, M. E., Schwoerer, C., \& Rosen, B. 1989. Effects of Alternative Training Methods on Self-Efficacy and Performance in Computer Software Training. Journal of Applied Psychology, 74(6): 884-891.

Glance, D. G., Forsey, M., \& Riley, M. 2013, May 5. The pedagogical foundations of massive open online courses. First Monday.

http://firstmonday.org/ojs/index.php/fm/article/view/4350/3673.

Gollwitzer, P. M., \& Brandstätter, V. 1997. Implementation intentions and effective goal pursuit. Journal of Personality and Social Psychology,73(1):186-199.

Greenlee, B. J., \& Karanxha, Z. 2010. A study of group dynamics in educational leadership cohort and non-cohort groups. Journal of Research on Leadership Education, 5(11): 
$357-382$.

Gregori, E. B., Zhang, J., Galván-Fernández, C., De, F., \& Fernández-Navarro, A. 2018. Learner support in MOOCs: Identifying variables linked to completion. Computers $\&$ Education, 122: 153-168.

Haythornthwaite, C. 2006. Facilitating collaboration in online learning. Journal of Asynchronous Learning Networks, 10(1): 7-24.

Hew, K. F., \& Cheung, W. S. 2014. Students' and instructors' use of massive open online courses (MOOCs): Motivations and challenges. Educational Research Review, 12: 4558.

Hillier, J., \& Dunn-Jensen, L. M. 2012. Groups Meet . . Teams Improve: Building Teams That Learn. Journal of Management Education, 37(5): 704-733.

Hillyard, C., Gillespie, D., \& Littig, P. 2010. University students' attitudes about learning in small groups after frequent participation. Active Learning in Higher Education, 11(1): 9-20.

Hockerts, K. 2018. The Effect of Experiential Social Entrepreneurship Education on Intention Formation in Students. Journal of Social Entrepreneurship, 9(3): 234-256.

Hogan, D. M., \& Tudge, J. R. H. 1999. Implications of Vygotsky's theory for peer learning. In A. O’Donnell \& A. King (Eds.), Cognitive perspectives on peer learning: 39-65. New York: Routledge.

Homans, G. 1958. Social Behavior as Exchange. American Journal of Sociology, 63(6): 597-606.

Hone, K. S., \& El Said, G. R. 2016. Exploring the factors affecting MOOC retention: A survey study. Computers and Education, 98: 157-168.

Hood, N., Littlejohn, A., \& Milligan, C. 2015. Context counts: How learners' contexts influence learning in a MOOC. Computers and Education, 91: 83-91.

Hooper, D., Coughlan, J., \& Mullen, M. 2008. Structural equation modelling: Guidelines for determining model fit. Business Research Methods, 6(1): 53-60.

Hsu, J. Y., Chen, C. C., \& Ting, P. F. 2018. Understanding MOOC continuance: An empirical examination of social support theory. Interactive Learning Environments, 119.

Huang, L., Zhang, J., \& Liu, Y. 2017. Antecedents of student MOOC revisit intention: Moderation effect of course difficulty. International Journal of Information Management, 37(2): 84-91.

Hummel, H. G. K., Burgos, D., Tattersall, C., Brouns, F., Kurvers, H., et al. 2005. Encouraging contributions in learning networks using incentive mechanisms. Journal of Computer Assisted Learning, 21(5): 355-365.

Janssen, J., Erkens, G., Kirschner, P. A., \& Kanselaar, G. 2009. Influence of group member familiarity on online collaborative learning. Computers in Human Behavior, 25(1): 161-170.

Järvelä, S., Volet, S., \& Järvenoja, H. 2010. Research on Motivation in Collaborative Learning: Moving Beyond the Cognitive-Situative Divide and Combining Individual and Social Processes. Educational Psychologist, 45(1): 15-27.

Johnson, D. W. 1970. The social psychology of education. Oxford, England: Holt, Rinehart 
\& Winston.

Johnson, D. W., \& Johnson, R. T. 1987. Learning together and alone: Cooperative, competitive, and individualistic learning, 2nd ed. Learning together and alone: Cooperative, competitive, and individualistic learning. Englewood Cliffs, NJ, US: Prentice-Hall, Inc.

Johnson, D. W., \& Johnson, R. T. 1989. Cooperation and competition: Theory and research. Interaction Book Company.

Johnson, D. W., \& Johnson, R. T. 2009. An Educational Psychology Success Story: Social Interdependence Theory and Cooperative Learning. Educational Researcher, 38(5): $365-379$.

Johnson, D. W., Johnson, R. T., \& Smith, K. 2007. The State of Cooperative Learning in Postsecondary and Professional Settings. Educational Psychology Review, 19(1): 1529.

Jona, K., \& Naidu, S. 2014. MOOCs: emerging research. Distance Education, 35(2): 141144.

Joo, Y. J., So, H.-J., \& Kim, N. H. 2018. Examination of relationships among students' selfdetermination, technology acceptance, satisfaction, and continuance intention to use KMOOCs. Computers \& Education, 122: 260-272.

Jordan, K. 2014. Initial trends in enrolment and completion of massive open online courses. International Review of Research in Open and Distance Learning, 15(1): 133-160.

Jung, Y., \& Lee, J. 2018. Learning Engagement and Persistence in Massive Open Online Courses (MOOCS). Computers \& Education, 122: 9-22.

Kannampuzha, M. J., \& Hockerts, K. 2019. Organizational social entrepreneurship: scale development and validation. Social Enterprise Journal, 15(3): 290-319.

Kautonen, T., van Gelderen, M., \& Tornikoski, E. T. 2013. Predicting entrepreneurial behaviour: a test of the theory of planned behaviour. Applied Economics, 45(6): 697707.

Kellogg, S., Booth, S., \& Oliver, K. 2014. A social network perspective on peer supported learning in MOOCs for educators. International Review of Research in Open and Distance Learning, 15(5): 263-289.

Kline, R. B. 2015. Principles and practice of structural equation modeling. Guilford publications.

Kolb, A. Y., \& Kolb, D. A. 2005. Learning styles and learning spaces: Enhancing experiential learning in higher education. Academy of Management Learning \& Education, 4(2): 193-212.

Koller, D., Ng, A., Do, C., \& Chen, Z. 2013. Retention and intention in massive open online courses: In depth. Educause Review, 48(3): 62-63.

Kraiger, K. 2008. Transforming Our Models of Learning and Development: Web-Based Instruction as Enabler of Third-Generation Instruction. Industrial and Organizational Psychology, 1(4): 454-467.

Kreijns, K., Kirschner, P., \& Jochems, W. 2003. Identifying the pitfalls for social interaction in computer-supported collaborative learning environments: a review of the research. Computers in Human Behavior, 19(3): 335-353. 
Ku, H.-Y., Tseng, H. W., \& Akarasriworn, C. 2013. Collaboration factors, teamwork satisfaction, and student attitudes toward online collaborative learning. Computers in Human Behavior, 29(3): 922-929.

Latané, B., Williams, K., \& Harkins, S. 1979. Many hands make light the work: The causes and consequences of social loafing. Journal of Personality and Social Psychology, 37(6): 822-832.

Li, B., Wang, X., \& Tan, S. C. 2018. What makes MOOC users persist in completing MOOCs? A perspective from network externalities and human factors. Computers in Human Behavior, 85: 385-395.

Li, N., Verma, H., Skevi, A., Guillaume, Z., \& Dillenbourg, P. 2014. MOOC Learning in Spontaneous Study Groups: Does Synchronously Watching Videos Make a Difference? Proceedings of the European MOOC Stakeholder Summit 2014, 88-94.

Liaw, S.-S. 2004. The theory of planned behaviour applied to search engines as a learning tool. Journal of Computer Assisted Learning, 20(4): 283-291.

Liden, R. C., Wayne, S. J., Jaworski, R. a., \& Bennett, N. 2004. Social loafing: A field investigation. Journal of Management, 30(2): 285-304.

Littlejohn, A., Hood, N., Milligan, C., \& Mustain, P. 2016. Learning in MOOCs: Motivations and self-regulated learning in MOOCs. The Internet and Higher Education, 29: 40-48.

Liu, W. C., Wang, C. K. J., Tan, O. S., Koh, C., \& Ee, J. 2009. A self-determination approach to understanding students' motivation in project work. Learning and Individual Differences, 19(1): 139-145.

MacDonald, J. 2003. Assessing online collaborative learning: Process and product. Computers and Education, 40(4): 377-391.

Manathunga, K., \& Hernández-Leo, D. 2015. Has Research on Collaborative Learning Technologies Addressed Massiveness? A Literature Review. Journal of Educational Technology \& Society, 18(4): 357-370.

Margaryan, A., Bianco, M., \& Littlejohn, A. 2015. Instructional quality of Massive Open Online Courses (MOOCs). Computers and Education, 80: 77-83.

Martinez-Lopez, R., Yot, C., Tuovila, I., \& Perera-Rodriguez, V.-H. 2017. Online SelfRegulated Learning Questionnaire in a Russian MOOC. Computers in Human Behavior, 75: 966-974.

Mattessich, P. W., \& Monsey, B. R. 1992. Collaboration: what makes it work. A review of research literature on factors influencing successful collaboration. Amherst $\mathrm{H}$. Wilder Foundation.

McAlpine, I. 2000. Collaborative learning online. Distance Education, 21(1): 66-80.

Moccozet, L., Tardy, C., Opprecht, W., \& Leonard, M. 2013. Gamification-based assessment of group work. 2013 International Conference on Interactive Collaborative Learning, ICL 2013, 171-179. IEEE.

Mondahl, M., \& Razmerita, L. 2014. Social Media, Collaboration and Social Learning--A Case-Study of Foreign Language Learning. Electronic Journal of E-Learning, 12(4): 339-352.

Moosmayer, D. C. 2012. A model of management academics' intentions to influence values. Academy of Management Learning and Education, 11(2): 155-173. 
Muthusamy, S. K., \& White, M. A. 2005. Learning and Knowledge Transfer in Strategic Alliances: A Social Exchange View. Organization Studies, 26(3): 415-441.

Nabeth, T., Razmerita, L., Angehrn, A., \& Roda, C. 2005. INCA: A cognitive multi-agents architecture for designing intelligent \& adaptive learning systems. Computer Science and Information Systems, 2(2): 99-114.

Niemiec, C. P., \& Ryan, R. M. 2009. Autonomy, competence, and relatedness in the classroom: Applying self-determination theory to educational practice. Theory and Research in Education, 7(2): 133-144.

Oncu, S., \& Cakir, H. 2011. Research in online learning environments: Priorities and methodologies. Computers \& Education, 57(1): 1098-1108.

Pajares, F., Prestin, A., Chen, J. A., \& Nabi, R. L. 2009. Social Cognitive Theory and Mass Media Effects. The SAGE Handbook of Media Processes and Effects: 283-297.

Panigrahi, R., Srivastava, P. R., \& Sharma, D. 2018. Online learning: Adoption, continuance, and learning outcome-A review of literature. International Journal of Information Management, 43: 1-14.

Park, S. Y. 2009. An analysis of the technology acceptance model in understanding University students' behavioral intention to use e-Learning. Educational Technology \& Society, 12(3): 150-162.

Passarelli, A. 2014. Harnessing the Power of a Massive Open Online Course (MOOC): Inspiring Leadership Through Emotional Intelligence. Academy of Management Learning \& Education, 25(7): 298-301.

Paulus, P. B., \& Nijstad, B. A. 2003. Group Creativity. Group Creativity: Innovation through Collaboration. Oxford University Press. http://www.oxfordscholarship.com/view/10.1093/acprof:oso/9780195147308.001.0001/ acprof-9780195147308.

Pedersen, S. T., Razmerita, L., \& Colleoni, E. 2014. Electronic Word-of-Mouth communication and consumer behaviour : an exploratory study of Danish social media communication influence. LSP Journal, 5(1): 112-131.

Pentland, B. T. 1999. Building Process Theory with Narrative: From Description to Explanation. Academy of Management Review, 24(4): 711-724.

Podsakoff, P. M., MacKenzie, S. B., Lee, J. Y., \& Podsakoff, N. P. 2003. Common Method Biases in Behavioral Research: A Critical Review of the Literature and Recommended Remedies. Journal of Applied Psychology, 88(5): 879-903.

Prince, M. 2004. Does Active Learning Work? A Review of the Research. Journal of Engineering Education, 93(3): 223-231.

Rafferty, P. D. 2013. Group Work in the MBA Classroom: Improving Pedagogical Practice and Maximizing Positive Outcomes With Part-Time MBA Students. Journal of Management Education, 37(5): 623-650.

Razmerita, L. 2011. An ontology-based framework for modeling user behavior-A case study in knowledge management. IEEE Transactions on Systems, Man, and Cybernetics Part A: Systems and Humans, 41(4): 772-783.

Razmerita, L., \& Kirchner, K. 2015. Collaboration and E-Collaboration: A Study of Factors that Influence Perceived Students' Group Performance. 48th Hawaii International Conference on System Sciences (HICSS): 33-42. 
Reich, J., \& Ruipérez-Valiente, J. A. 2019. The MOOC pivot. Science, 363(6423): 130-131.

Rienties, B., Giesbers, B., Tempelaar, D., Lygo-Baker, S., Segers, M., et al. 2012. The role of scaffolding and motivation in CSCL. Computers \& Education, 59(3): 893-906.

Rothkrantz, L. 2015. How Social Media Facilitate Learning Communities and Peer Groups around MOOCS. International Journal of Human Capital and Information Technology Professionals, 6(1): 1-13.

Sanz-Martínez, L., Martínez-Monés, A., Bote-Lorenzo, M. L., Muñoz-Cristóbal, J. A., \& Dimitriadis, Y. 2017. Automatic group formation in a MOOC based on students' activity criteria. Lecture Notes in Computer Science, 10474 LNCS: 179-193.

Sarason, I. G., Levine, H. M., Basham, R. B., \& Sarason, B. R. 1983. Assessing social support: The Social Support Questionnaire. Journal of Personality and Social Psychology, 44(1): 127-139.

Schaefer, R. A. B., \& Palanski, M. E. 2014. Emotional Contagion at Work An In-Class Experiential Activity. Journal of Management Education, 38(4): 533-559.

Shapiro, H. B., Lee, C. H., Wyman Roth, N. E., Li, K., Çetinkaya-Rundel, M., et al. 2017. Understanding the massive open online course (MOOC) student experience: An examination of attitudes, motivations, and barriers. Computers and Education, 110: 3550.

Sharda, R., Romano, N., Lucca, J., Weiser, M., Scheets, G., et al. 2004. Foundation for the Study of Computer-Supported Collaborative Learning Requiring Immersive Presence. Journal of Management Information Systems, 20(4): 31-64.

Siragusa, L., \& Dixon, K. C. 2009. Theory of planned behaviour: Higher educatio students' attitudes towards ICT-based learning interactions. Same places, different spaces. Proceedings ascilite Auckland 2009, 969-980.

Slavich, B., \& Svejenova, S. 2016. Managing Creativity: A Critical Examination, Synthesis, and New Frontiers. European Management Review, 13: 237-250.

Smith, G. G., Sorensen, C., Gump, A., Heindel, A. J., Caris, M., et al. 2011. Overcoming student resitance to group work: Online versus face-to-face. Internet and Higher Education, (14): 121-128.

So, H.-J., \& Brush, T. A. 2008. Student perceptions of collaborative learning, social presence and satisfaction in a blended learning environment: Relationships and critical factors. Computers \& Education, 51(1): 318-336.

Sonnenwald, D. H., \& Pierce., L. G. 2000. Information behavior in dynamic group work contexts: interwoven situational awareness, dense social networks and contested collaboration in command and control. Information Processing \& Management, 36(3): 461-479.

Stahl, G., Koschmann, T., \& Suthers, D. 2006. Computer-supported collaborative learning : An historical perspective. In R. K. Sawyer (Ed.), Cambridge Handbook of Learning Science: 409-426. Cambridge: Cambridge University Press.

Staubitz, T., \& Meinel, C. 2017. Collaboration and Teamwork on a MOOC Platform. Proceedings of the Fourth ACM Conference on Learning@Scale - L@S '17, 165168. New York, New York, USA: ACM Press.

Staubitz, T., Pfeiffer, T., Renz, J., Willems, C., \& Meinel, C. 2015. Collaborative Learning in a Mooc Environment. iCeri15 Proceedings: 8237-8246. 
Swan, K., \& Shih, L. F. 2005. On the nature and development of social presence in online course discussions. Journal of Asynchronous Learning Networks, 9(3): 115-136.

Taras, V., Caprar, D. V., Rottig, D., Sarala, R. M., Zakaria, N., et al. 2013. A Global Classroom? Evaluating the Effectiveness of Global Virtual Collaboration as a Teaching Tool in Management Education. Academy of Management Learning \& Education, 12(3): 414-435.

Tawfik, A. A., Reeves, T. D., Stich, A. E., Gill, A., Hong, C., et al. 2017. The nature and level of learner-learner interaction in a chemistry massive open online course (MOOC). Journal of Computing in Higher Education, 29(3): 411-431.

Teo, T. 2012. Examining the intention to use technology among pre-service teachers: an integration of the Technology Acceptance Model and Theory of Planned Behavior. Interactive Learning Environments, 20(1): 3-18.

Thibaut, J. W., \& Kelley, H. H. 1959. The Social Psychology of Groups. American Sociological Review.

Turel, O., \& Zhang, Y. 2011. Should I e-collaborate with this group? A multilevel model of usage intentions. Information \& Management, 48(1): 62-68.

Venkatesh, V., Croteau, A.-M., \& Rabah, J. 2014. Perceptions of effectiveness of instructional uses of technology in higher education in an era of Web 2.0. 47th Hawaii International Conference on System Sciences (HICSS), 110-119. IEEE.

Venkatesh, V., Thong, J. Y. L., \& Xu, X. 2012. Consumer Acceptance and Use of Information Technology: Extending the Unified Theory of Acceptance and Use of Technology. MIS Quarterly, 36(1): 157-178.

Vygotsky, L. S. 1978. Interaction between Learning and Development. In V. L. Semyonovich (Ed.), Mind in Society: 79-91. Cambridge, MA: Harvard Univeristy Press.

Wang, S. L., \& Lin, S. S. J. 2007. The effects of group composition of self-efficacy and collective efficacy on computer-supported collaborative learning. Computers in Human Behavior, 23(5): 2256-2268.

Wang, W., Guo, L., He, L., \& Wu, Y. J. 2019. Effects of social-interactive engagement on the dropout ratio in online learning: insights from MOOC. Behaviour \& Information Technology, 38(6): 621-636.

Wen, M., Yang, D., \& Rosé, C. P. 2015. Virtual Teams in Massive Open Online Courses. Proc. of International Conference on Artificial Intelligence in Education: 820-824. Springer, Cham.

Whitaker, J., New, J. R., \& Ireland, R. D. 2016. MOOCs and the Online Delivery of Business Education What's new? What's not? What now? Academy of Management Learning and Education, 15(2): 345-356.

Whitehead, A. N. 1929. The Aims of Education and other essays. New York: The Free Press.

Wise, A. F., \& Cui, Y. 2018. Learning communities in the crowd: Characteristics of content related interactions and social relationships in MOOC discussion forums. Computers $\&$ Education, 122: 221-242.

Wood, C., Conner, M., Miles, E., Sandberg, T., Taylor, N., et al. 2016. The Impact of Asking Intention or Self-Prediction Questions on Subsequent Behavior: A Meta-Analysis.

Personality and Social Psychology Review, 20(3): 245-268. 
$\mathrm{Wu}, \mathrm{B} .$, \& Chen, X. 2017. Continuance intention to use MOOCs: Integrating the technology acceptance model (TAM) and task technology fit (TTF) model. Computers in Human Behavior, 67: 221-232.

Yuan, L., \& Powell, S. 2013. MOOCs and Open Education: Implications for Higher Education. CETIS White Paper. https://e-space.mmu.ac.uk/619735/1/MOOCs-andOpen-Education.pdf.

Zhang, Q., Peck, K. L., Hristova, A., Jablokow, K. W., Hoffman, V., et al. 2016. Exploring the communication preferences of MOOC learners and the value of preference-based groups: Is grouping enough? Educational Technology Research and Development, 64(4): 809-837.

Zheng, Z., Vogelsang, T., \& Pinkwart, N. 2015. The Impact of Small Learning Group Composition on Student Engagement and Success in a MOOC. Proc. of the 8th International Conference on Educational Data Mining, 500-503.

Zhenghao, C., Alcorn, B., Christensen, G., \& Eriksson, N. 2015. Who's benefiting from MOOCs, and why. Harvard Business Review, 25(Sept): 2-8.

Zhou, M. 2016. Chinese university students' acceptance of MOOCs: A self-determination perspective. Computers \& Education, 92: 194-203.

Zhu, Y., Rooney, D., \& Phillips, N. 2016. A Practice-Based Wisdom Perspective for Social Entrepreneurship Learning and Education. Academy of Management Learning \& Education, 15(3): 607-625.

Zimet, G. D., Dahlem, N. W., Zimet, S. G., \& Farley, G. K. 1988. The Multidimensional Scale of Perceived Social Support. Journal of Personality Assessment, 52(1): 30-41. 
Table 1: Overview of Primary Research Streams in MOOCs

\begin{tabular}{|c|c|c|}
\hline Research Streams & Themes & Selected References \\
\hline $\begin{array}{l}\text { Groups \& Virtual } \\
\text { Teamwork in MOOCs }\end{array}$ & $\begin{array}{l}\text { - Group work may prevent high dropout } \\
\text { rate from MOOC } \\
\text { - Group formation problems can be solved } \\
\text { with algorithms } \\
\text { Collaboration challenges: } \\
>\text { place and time distance } \\
>\text { group formation } \\
>\text { diverse group members and } \\
\text { viewpoints } \\
>\text { different group work perceptions } \\
\text { according to different gender and } \\
\text { culture }\end{array}$ & $\begin{array}{l}\text { (Wen et al., 2015) } \\
\text { (Rothkrantz, 2015) } \\
\text { (Staubitz, Pfeiffer, Renz, Willems, \& } \\
\text { Meinel, 2015) } \\
\text { (Zheng, Vogelsang, \& Pinkwart, 2015) } \\
\text { (Zhang et al., 2016) } \\
\text { (Staubitz \& Meinel, 2017) } \\
\text { (Sanz-Martínez et al., 2017) } \\
\text { (Bayeck, Hristova, Jablokow, \& } \\
\text { Bonafini, 2018) }\end{array}$ \\
\hline $\begin{array}{l}\text { Online Interaction } \\
\text { and Participation } \\
\text { Inside and Outside } \\
\text { MOOCs }\end{array}$ & $\begin{array}{l}\text { - Learners interact discussion forums in } \\
\text { - Interaction in MOOCs can lead to } \\
\text { relationship-building } \\
\text { - Dicussion forums around specific topics } \\
\text { have short life } \\
\text { - MOOC students prefer to learn in groups } \\
\text { through face-to-face interaction (if } \\
\text { possible) } \\
\text { - Face-to-face" study groups improve } \\
\text { motivation, engagement and learning in } \\
\text { MOOCs }\end{array}$ & $\begin{array}{l}\text { (Wise \& Cui, 2018) } \\
\text { (Gillani \& Eynon, 2014) } \\
\text { (Li et al., 2014) } \\
\text { (Mondahl \& Razmerita, 2014) } \\
\text { (Chen \& Chen, 2015) }\end{array}$ \\
\hline $\begin{array}{l}\text { MOOC Learners' } \\
\text { Motivations and } \\
\text { Learning Strategies }\end{array}$ & $\begin{array}{l}\text { Learning motives: } \\
\text { - Desire to learn about new topic } \\
\text { - } \quad \text { Extend knowledge } \\
\text { - Curiosity } \\
\text { - Collect certificates } \\
\text { Learning challenges: } \\
\text { - Lack of focus in discussion forum } \\
\text { - Failure to understand content and no help } \\
\text { - Lack of time } \\
\text { Learning motivation and strategies: } \\
\text { - high self-efficacy due to prior knowledge } \\
\text { - increases motivation } \\
\text { - impocial interactions in online groups are } \\
\text { - social interaction (e.g., in forums) } \\
\text { increases motivation }\end{array}$ & $\begin{array}{l}\text { (Hew \& Cheung, 2014) } \\
\text { (Barak et al., 2016) } \\
\text { (Littlejohn, Hood, Milligan, \& Mustain, } \\
\text { 2016) } \\
\text { (Martinez-Lopez, Yot, Tuovila, \& } \\
\text { Perera-Rodriguez, 2017) }\end{array}$ \\
\hline
\end{tabular}




\begin{tabular}{|c|c|c|}
\hline $\begin{array}{l}\text { Attitude toward } \\
\text { MOOC }\end{array}$ & $\begin{array}{l}\text { - Knowledge, work, convenience, and } \\
\text { personal interest as most important } \\
\text { motivations } \\
\text { - Lack of time, previous bad experience and } \\
\text { inadequate background as biggest } \\
\text { challenges } \\
\text { - Attitude toward MOOC and perceived } \\
\text { behavioral control most relevant for } \\
\text { intension to use MOOC }\end{array}$ & $\begin{array}{l}\text { (Zhou, 2016) } \\
\text { (Shapiro et al., 2017) }\end{array}$ \\
\hline $\begin{array}{l}\text { MOOC Revisit or } \\
\text { Continue and } \\
\text { Completion Intention }\end{array}$ & $\begin{array}{l}\text { Factors affecting students' persistence to } \\
\text { finish the MOOC: } \\
\text { - Satisfaction } \\
\text { - Communication and exchanging ideas } \\
\text { with classmates and instructors } \\
\text { - Network benefits, user preferences and } \\
\text { intrinsic /extrinsic motivation } \\
\text { - Quality of teaching material, teachers' } \\
\text { presence and interaction with students }\end{array}$ & $\begin{array}{l}\text { (Jordan, 2014) } \\
\text { (Alraimi et al., 2015) } \\
\text { (Hone \& El Said, 2016) } \\
\text { (Wu \& Chen, 2017) } \\
\text { (Huang et al., 2017) } \\
\text { (Chen, Lee, \& Hsiao, 2018) } \\
\text { (Joo et al., 2018) } \\
\text { (Li, Wang, \& Tan, 2018) } \\
\text { (Gregori, Zhang, Galván-Fernández, } \\
\text { De, \& Fernández-Navarro, 2018) } \\
\text { (Jung \& Lee, 2018) } \\
\text { (Hsu et al., 2018) }\end{array}$ \\
\hline
\end{tabular}


Table 2: Descriptive Statistics for Survey Respondents

\begin{tabular}{|c|c|c|c|}
\hline Demographic Characteristic & $t_{1}[$ Sample $N=2,517]$ & $t_{2}[$ Sample $N=143]$ & Paired $t$-Test \\
\hline \multicolumn{4}{|l|}{ Gender } \\
\hline Male & $1,125[44.70 \%]$ & 60 [41.96\%] & \multirow{3}{*}{$t=.000 ; p>.05$} \\
\hline Female & $1,356[53.87 \%]$ & 83 [58.04\%] & \\
\hline Unwilling to disclose & 36 [1.43\%] & $0[0.00 \%]$ & \\
\hline \multicolumn{4}{|l|}{ Age } \\
\hline Age 19-29 & $1,805[71.71 \%]$ & 67 [46.85\%] & \multirow{5}{*}{$t=.000 ; p>.05$} \\
\hline Age 30-49 & 609 [24.20\%] & $62[43.36 \%]$ & \\
\hline Age 50-64 & 72 [2.86\%] & 11 [7.69\%] & \\
\hline Age 65+ & 0 [0.00\%] & 0 [0.00\%] & \\
\hline Unwilling to disclose & $31[1.23 \%]$ & $3[2.10 \%]$ & \\
\hline \multicolumn{4}{|l|}{ Educational Level } \\
\hline College education or higher & 2,191 [87.05\%] & 135 [94.41\%] & \multirow{3}{*}{$t=-.001 ; p>.05$} \\
\hline Less than college education & 293 [11.64\%] & 7 [4.90\%] & \\
\hline Unwilling to disclose & 33 [1.31\%] & $1[0.70 \%]$ & \\
\hline \multicolumn{4}{|l|}{ Income } \\
\hline$\$ 0-\$ 24,999$ & $1,031[40.96 \%]$ & $64[44.76 \%]$ & \multirow{6}{*}{$t=.000 ; p>.05$} \\
\hline$\$ 25,000-\$ 49,999$ & 537 [21.33\%] & $24[16.78 \%]$ & \\
\hline$\$ 50,000-\$ 74,999$ & 265 [10.53\%] & $14[9.79 \%]$ & \\
\hline$\$ 75,000-\$ 99,999$ & 197 [7.83\%] & 13 [9.09\%] & \\
\hline$\$ 100,000+$ & 339 [13.47\%] & $22[15.38 \%]$ & \\
\hline Unwilling to disclose & $148[5.88 \%]$ & $6[4.20 \%]$ & \\
\hline
\end{tabular}

Table 3: Test of Common Method Bias

\begin{tabular}{|c|c|c|c|c|c|c|c|c|}
\hline Model & $\begin{array}{c}\chi^{2} d f \\
\text { [smaller] }\end{array}$ & $\begin{array}{c}\chi^{2} / d f \\
{[<3.0]}\end{array}$ & $\begin{array}{c}\text { GFI } \\
{[>0.9]}\end{array}$ & $\begin{array}{l}\text { AGFI } \\
{[>0.8]}\end{array}$ & $\begin{array}{c}\text { RMR } \\
{[<0.05]}\end{array}$ & $\begin{array}{l}\text { RMSEA } \\
{[<0.06]}\end{array}$ & $\begin{array}{c}\text { NFI } \\
{[>0.9]}\end{array}$ & $\begin{array}{c}\text { CFI } \\
{[>0.9]}\end{array}$ \\
\hline \multicolumn{9}{|c|}{ Model $t_{1}$ [Sample $N=2,517$ ] } \\
\hline $\begin{array}{l}\text { Original Model (w/ } \\
8 \text { constructs) }\end{array}$ & $\chi_{377}^{2}=2,384.31$ & 6.23 & 0.93 & 0.91 & 0.024 & 0.051 & 0.97 & 0.97 \\
\hline $\begin{array}{l}\text { Singular Construct } \\
\text { Model }\end{array}$ & $\chi^{2} 405=13,106.75$ & 32.36 & 0.68 & 0.63 & 0.067 & 0.130 & 0.82 & 0.82 \\
\hline \multicolumn{9}{|c|}{ Model $t_{2}$ [Sample $N=143$ ] } \\
\hline $\begin{array}{l}\text { Original Model (w/ } \\
5 \text { constructs) }\end{array}$ & $\chi_{67}^{2}=103.41$ & 1.54 & 0.91 & 0.86 & 0.047 & 0.060 & 0.94 & 0.98 \\
\hline $\begin{array}{l}\text { Singular Construct } \\
\text { Model }\end{array}$ & $\chi^{2} 77=848.49$ & 11.02 & 0.49 & 0.31 & 0.021 & 0.030 & 0.49 & 0.51 \\
\hline
\end{tabular}


Table 4: Inter-Construct Correlation Matrix for Model $t_{1}$ [Sample $\left.N=2,517\right]$

\begin{tabular}{|c|c|c|c|c|c|c|c|c|c|c|c|c|}
\hline & $\begin{array}{c}\text { Mean } \\
\text { (Std Dev) }\end{array}$ & $\begin{array}{c}\text { Average Variance } \\
\text { Extracted (AVE) } \\
{[\geq 0.50]}\end{array}$ & $\begin{array}{c}\text { Composite } \\
\text { Reliability } \\
{[\geq 0.70]}\end{array}$ & $\begin{array}{c}\text { Cronbach's } \\
\text { Alpha }(\alpha) \\
{[\geq 0.70]}\end{array}$ & ATT & NCE & COI & CSE & INT & COE & CPE & CTE \\
\hline ATT & $4.23(0.56)$ & 0.62 & 0.91 & 0.88 & 0.79 & & & & & & & \\
\hline NCE & $3.28(0.70)$ & 0.50 & 0.83 & 0.74 & -0.15 & 0.70 & & & & & & \\
\hline COI & $3.62(0.56)$ & 0.55 & 0.79 & 0.60 & 0.30 & -0.05 & 0.75 & & & & & \\
\hline CSE & $3.87(0.51)$ & 0.67 & 0.89 & 0.84 & 0.43 & -0.14 & 0.31 & 0.82 & & & & \\
\hline INT & $3.63(0.66)$ & 0.76 & 0.91 & 0.84 & 0.45 & -0.16 & 0.33 & 0.37 & 0.87 & & & \\
\hline COE & $4.10(0.58)$ & 0.65 & 0.85 & 0.73 & 0.50 & -0.07 & 0.31 & 0.40 & 0.37 & 0.80 & & \\
\hline CPE & $3.98(0.50)$ & 0.62 & 0.87 & 0.80 & 0.43 & -0.11 & 0.29 & 0.49 & 0.40 & 0.49 & 0.79 & \\
\hline CTE & $3.86(0.79)$ & 0.74 & 0.85 & 0.70 & 0.26 & 0.00 & 0.15 & 0.19 & 0.19 & 0.33 & 0.30 & 0.86 \\
\hline
\end{tabular}

Note: ATT - Collaborative Attitude; NCE - Negative Collaborative Experience; COI - Communal Influence; CSE - Communal Support Expectancy; INT - Collaborative Intentions; COE - Collaborative Outcome Expectancy; CPE - Collaborative Process Efficacy; CTE - Collaborative Technology Experience

Table 5: Inter-Construct Correlation Matrix for Model $t_{2}$ [Sample $N=143$ ]

\begin{tabular}{|c|c|c|c|c|c|c|c|c|c|}
\hline & $\begin{array}{c}\text { Mean } \\
\text { (Std Dev) }\end{array}$ & $\begin{array}{c}\text { Average Variance } \\
\text { Extracted (AVE) } \\
{[\geq 0.50]}\end{array}$ & $\begin{array}{c}\text { Composite } \\
\text { Reliability } \\
{[\geq 0.70]}\end{array}$ & $\begin{array}{c}\text { Cronbach's } \\
\text { Alpha }(\alpha) \\
{[\geq 0.70]}\end{array}$ & EGW & INT & LEX & NOV & RET \\
\hline EGW & $2.75(1.08)$ & 0.89 & 0.96 & 0.94 & 0.94 & & & & \\
\hline INT & $3.82(0.66)$ & 0.73 & 0.89 & 0.81 & 0.23 & 0.87 & & & \\
\hline LEX & $4.28(0.79)$ & 0.76 & 0.93 & 0.90 & 0.08 & -0.07 & 0.85 & & \\
\hline NOV & $3.80(0.82)$ & 0.89 & 0.96 & 0.94 & 0.24 & 0.16 & 0.34 & 0.87 & \\
\hline RET & $4.26(1.21)$ & 1.00 & 1.00 & 1.00 & 0.45 & 0.08 & 0.28 & 0.23 & 1.00 \\
\hline
\end{tabular}

Note: EGW - Engagement in Group Work; INT - Collaborative Intentions; LEX - Learning Experience; NOV - Idea Novelty; RET - Course Retention 


\section{Appendix A: List of Measurement Items}

\begin{tabular}{|c|c|c|c|c|}
\hline Construct & Definition & Measure & $\begin{array}{c}\text { Mean } \\
\text { (Std Dev) }\end{array}$ & $\begin{array}{l}\text { Factorial } \\
\text { Loading }\end{array}$ \\
\hline \multicolumn{5}{|c|}{$\begin{array}{l}\text { Original Survey Questionnaire (measured via 5-point Likert Scale unless stated otherwise) [Sample } N=2,517] \\
\text { (collected at the onset of the course) }\end{array}$} \\
\hline \multirow{3}{*}{$\begin{array}{l}\text { Communal } \\
\text { Influence } \\
\text { (COI) }\end{array}$} & \multirow{3}{*}{$\begin{array}{l}\text { Degree to which an } \\
\text { individual believes } \\
\text { that their peers } \\
\text { want them to } \\
\text { engage in group } \\
\text { work }\end{array}$} & $\begin{array}{l}\text { Most of my peers would expect me to contribute } \\
\text { toward optional group work. }\end{array}$ & $3.74(0.72)$ & 0.73 \\
\hline & & $\begin{array}{l}\text { Most of my peers would contribute toward } \\
\text { optional group work. }\end{array}$ & $3.59(0.73)$ & 0.81 \\
\hline & & $\begin{array}{l}\text { Most of my peers would argue that group work } \\
\text { enhances their effectiveness. }\end{array}$ & $3.52(0.81)$ & 0.69 \\
\hline \multirow{4}{*}{$\begin{array}{l}\text { Communal } \\
\text { Support } \\
\text { Expectancy } \\
\text { (CSE) }\end{array}$} & \multirow{4}{*}{$\begin{array}{l}\text { Degree to which an } \\
\text { individual believes } \\
\text { that their peers will } \\
\text { support their } \\
\text { engagement in } \\
\text { group work }\end{array}$} & I am sure my group members would support me. & $3.84(0.63)$ & 0.84 \\
\hline & & People in my group would back me up. & $3.83(0.64)$ & 0.83 \\
\hline & & I would receive help from my group. & $3.96(0.56)$ & 0.86 \\
\hline & & $\begin{array}{l}\text { I could count on my group members to help me } \\
\text { when I face difficulties. }\end{array}$ & $3.85(0.69)$ & 0.74 \\
\hline \multirow{4}{*}{$\begin{array}{l}\text { Collaborative } \\
\text { Process } \\
\text { Efficacy (CPE) }\end{array}$} & \multirow{4}{*}{$\begin{array}{l}\text { Degree to which an } \\
\text { individual is } \\
\text { confident in their } \\
\text { ability to function } \\
\text { efficaciously in } \\
\text { groups }\end{array}$} & I am good at group work. & $4.01(0.63)$ & 0.83 \\
\hline & & $\begin{array}{l}\text { If there was conflict in my group work, I would be } \\
\text { able to solve it amicably. }\end{array}$ & $4.01(0.63)$ & 0.73 \\
\hline & & $\begin{array}{l}\text { I would be able to motivate group members to } \\
\text { contribute toward the group effort. }\end{array}$ & $4.01(0.63)$ & 0.78 \\
\hline & & I possess the skills required for group work. & $4.01(0.62)$ & 0.81 \\
\hline \multirow{3}{*}{$\begin{array}{l}\text { Collaborative } \\
\text { Outcome } \\
\text { Expectancy } \\
\text { (COE) }\end{array}$} & \multirow{3}{*}{$\begin{array}{l}\text { Degree to which an } \\
\text { individual believes } \\
\text { that group work is } \\
\text { instrumental in } \\
\text { achieving tangible } \\
\text { outcomes }\end{array}$} & I have usually enjoyed group work collaboration. & $3.96(0.76)$ & 0.82 \\
\hline & & $\begin{array}{l}\text { Group work collaboration has enabled me to learn } \\
\text { new things. }\end{array}$ & $4.20(0.70)$ & 0.78 \\
\hline & & $\begin{array}{l}\text { Group work collaboration has given me new } \\
\text { perspectives on the topic I have worked on. }\end{array}$ & $4.13(0.69)$ & 0.81 \\
\hline \multirow{6}{*}{$\begin{array}{l}\text { Collaborative } \\
\text { Attitude (ATT) }\end{array}$} & \multirow{6}{*}{$\begin{array}{l}\text { An individual's } \\
\text { positive or negative } \\
\text { feelings about } \\
\text { engaging in group } \\
\text { work }\end{array}$} & Group work is effective. & $4.06(0.74)$ & 0.72 \\
\hline & & Group work is important. & $4.31(0.65)$ & 0.81 \\
\hline & & Group work is relevant. & $4.25(0.65)$ & 0.81 \\
\hline & & Group work is unnecessary. & $4.21(0.76)$ & 0.78 \\
\hline & & Group work is irrelevant. & $4.26(0.72)$ & 0.80 \\
\hline & & Group work is a waste of time. & $4.26(0.76)$ & 0.81 \\
\hline \multirow{3}{*}{$\begin{array}{l}\text { Collaborative } \\
\text { Intentions } \\
\text { (INT) }\end{array}$} & \multirow{3}{*}{$\begin{array}{l}\text { An indication of an } \\
\text { individual's } \\
\text { readiness to engage } \\
\text { in group work }\end{array}$} & $\begin{array}{l}\text { I intend to join the optional group work in this } \\
\text { MOOC. }\end{array}$ & $3.76(0.73)$ & 0.83 \\
\hline & & $\begin{array}{l}\text { I am planning to take an active part in the optional } \\
\text { group work. }\end{array}$ & $3.69(0.75)$ & 0.86 \\
\hline & & $\begin{array}{l}\text { I expect to spend considerable time on optional } \\
\text { group work in this MOOC. }\end{array}$ & $3.39(0.82)$ & 0.76 \\
\hline $\begin{array}{l}\text { Collaborative } \\
\text { Technology }\end{array}$ & $\begin{array}{l}\text { Degree to which an } \\
\text { individual possesses }\end{array}$ & $\begin{array}{l}\text { I have used online tools as part of my previous } \\
\text { group work. }\end{array}$ & $3.58(1.16)$ & 0.75 \\
\hline
\end{tabular}




\begin{tabular}{|c|c|c|c|c|}
\hline $\begin{array}{l}\text { Experience } \\
\text { (CTE) }\end{array}$ & $\begin{array}{l}\text { previous experience } \\
\text { with utilizing } \\
\text { collaborative } \\
\text { technology for } \\
\text { group work }\end{array}$ & $\begin{array}{l}\text { E-collaboration tools are very useful to support } \\
\text { group work. }\end{array}$ & $4.01(0.76)$ & 0.96 \\
\hline \multirow{5}{*}{$\begin{array}{l}\text { Negative } \\
\text { Collaborative } \\
\text { Experience } \\
\text { (NCE) }\end{array}$} & \multirow{5}{*}{$\begin{array}{l}\text { Degree to which an } \\
\text { individual has } \\
\text { experienced } \\
\text { obstacles in group } \\
\text { work based on } \\
\text { previous } \\
\text { experience(s) }\end{array}$} & $\begin{array}{l}\text { I have experienced lack of coordination in previous } \\
\text { group work. }\end{array}$ & $3.51(0.95)$ & 0.70 \\
\hline & & $\begin{array}{l}\text { I have experienced lack of trust among team } \\
\text { members in previous group work. }\end{array}$ & $3.06(1.03)$ & 0.67 \\
\hline & & $\begin{array}{l}\text { I have experienced difficulties due to different } \\
\text { educational backgrounds in previous group work. }\end{array}$ & $2.96(1.04)$ & 0.73 \\
\hline & & $\begin{array}{l}\text { I have experienced difficulties due to different } \\
\text { levels of knowledge in previous group work. }\end{array}$ & $3.33(0.98)$ & 0.77 \\
\hline & & $\begin{array}{l}\text { I have experienced difficulties due to lack of } \\
\text { commitment in previous group work. }\end{array}$ & $3.54(0.96)$ & 0.63 \\
\hline \multicolumn{5}{|c|}{$\begin{array}{l}\text { Course Evaluation Survey (measured via 5-point Likert Scale unless stated otherwise) [Sample } \mathbf{N}=143 \text { ] } \\
\text { (collected at the end of the course) }\end{array}$} \\
\hline \multirow{3}{*}{$\begin{array}{l}\text { Collaborative } \\
\text { Intentions } \\
\text { (INT) }\end{array}$} & \multirow{3}{*}{$\begin{array}{l}\text { An indication of an } \\
\text { individual's } \\
\text { readiness to engage } \\
\text { in group work }\end{array}$} & $\begin{array}{l}\text { I intend to join the optional group work in this } \\
\text { MOOC. }\end{array}$ & $3.92(0.72)$ & 0.83 \\
\hline & & $\begin{array}{l}\text { I am planning to take an active part in the optional } \\
\text { group work. }\end{array}$ & $3.93(0.68)$ & 0.89 \\
\hline & & $\begin{array}{l}\text { I expect to spend considerable time on optional } \\
\text { group work in this MOOC. }\end{array}$ & $3.55(0.89)$ & 0.89 \\
\hline \multirow[t]{3}{*}{$\begin{array}{l}\text { Engagement } \\
\text { in Group } \\
\text { Work (EGW) }\end{array}$} & \multirow[t]{3}{*}{$\begin{array}{l}\text { Degree to which an } \\
\text { individual engages } \\
\text { in group work } \\
\text { during the course }\end{array}$} & $\begin{array}{l}\text { How did you engage in group work during the } \\
\text { MOOC? } \\
\text { - } 1 \text { - Not at all } \\
\text { - } 2 \text { - I was a passive member } \\
\text { - } 3 \text { - I was slightly active } \\
\text { - } 4 \text { - I was an active group member } \\
\text { - } 5 \text { - I was involved in leading the group }\end{array}$ & 3.15 (1.39) & 0.94 \\
\hline & & $\begin{array}{l}\text { How often did you engage in group work during } \\
\text { the MOOC? } \\
\begin{array}{l}\text { - } 1 \text { - Never } \\
\text { - } 2 \text {-Only very rarely } \\
\text { - Occasionally } \\
\text { - } 4 \text {-Often } \\
\text { - } 5 \text { - Nearly every week }\end{array}\end{array}$ & $3.33(1.53)$ & 0.95 \\
\hline & & $\begin{array}{l}\text { I have participated in group work as part of the } \\
\text { MOOC. }\end{array}$ & $2.22(0.79)$ & 0.94 \\
\hline $\begin{array}{l}\text { Course } \\
\text { Retention } \\
\text { (RET) }\end{array}$ & $\begin{array}{l}\text { Degree of course } \\
\text { participation }\end{array}$ & $\begin{array}{l}\text { Did you participate in the whole MOOC or did you } \\
\text { drop out at some point and never come back? } \\
\text { - } 1-\text { I never really got started with the MOOC. } \\
\text { - } 2-I \text { dropped out after the first quarter. } \\
\text { - } 3-\text { I dropped out after the first half. } \\
\text { - } 4-I \text { dropped out after about } 9 \text { weeks. } \\
\text { - } 5-\text { I continued the MOOC until the end. }\end{array}$ & $4.26(1.21)$ & 1.00 \\
\hline
\end{tabular}




\begin{tabular}{|c|c|c|c|c|}
\hline \multirow[t]{4}{*}{$\begin{array}{l}\text { Idea Novelty } \\
\text { (INO) }\end{array}$} & \multirow{4}{*}{$\begin{array}{l}\text { Degree to which an } \\
\text { individual views the } \\
\text { solution to the } \\
\text { course assignment } \\
\text { to be novel }\end{array}$} & $\begin{array}{l}\text { We are helping our beneficiaries in a way that } \\
\text { nobody else has done before. }\end{array}$ & $3.74(0.93)$ & 0.89 \\
\hline & & $\begin{array}{l}\text { Our approach is radically different from what our } \\
\text { peers are doing. }\end{array}$ & $3.62(0.96)$ & 0.85 \\
\hline & & $\begin{array}{l}\text { We have identified an opportunity to address a } \\
\text { social problem in a new way. }\end{array}$ & $4.05(0.87)$ & 0.89 \\
\hline & & $\begin{array}{l}\text { The solution to the social problem that we are } \\
\text { offering is unique. }\end{array}$ & $3.74(0.96)$ & 0.87 \\
\hline \multirow{3}{*}{$\begin{array}{l}\text { Learning } \\
\text { Experience } \\
\text { (LEX) }\end{array}$} & \multirow{3}{*}{$\begin{array}{l}\text { Degree to which an } \\
\text { individual is positive } \\
\text { about his/her } \\
\text { experience with the } \\
\text { course }\end{array}$} & $\begin{array}{l}\text { The course has extensively increased my } \\
\text { knowledge of the subject. }\end{array}$ & $4.22(0.99)$ & 0.86 \\
\hline & & My overall impression of the course is positive. & $4.36(0.91)$ & 0.90 \\
\hline & & I will recommend this course to my peers. & $4.27(0.86)$ & 0.79 \\
\hline
\end{tabular}




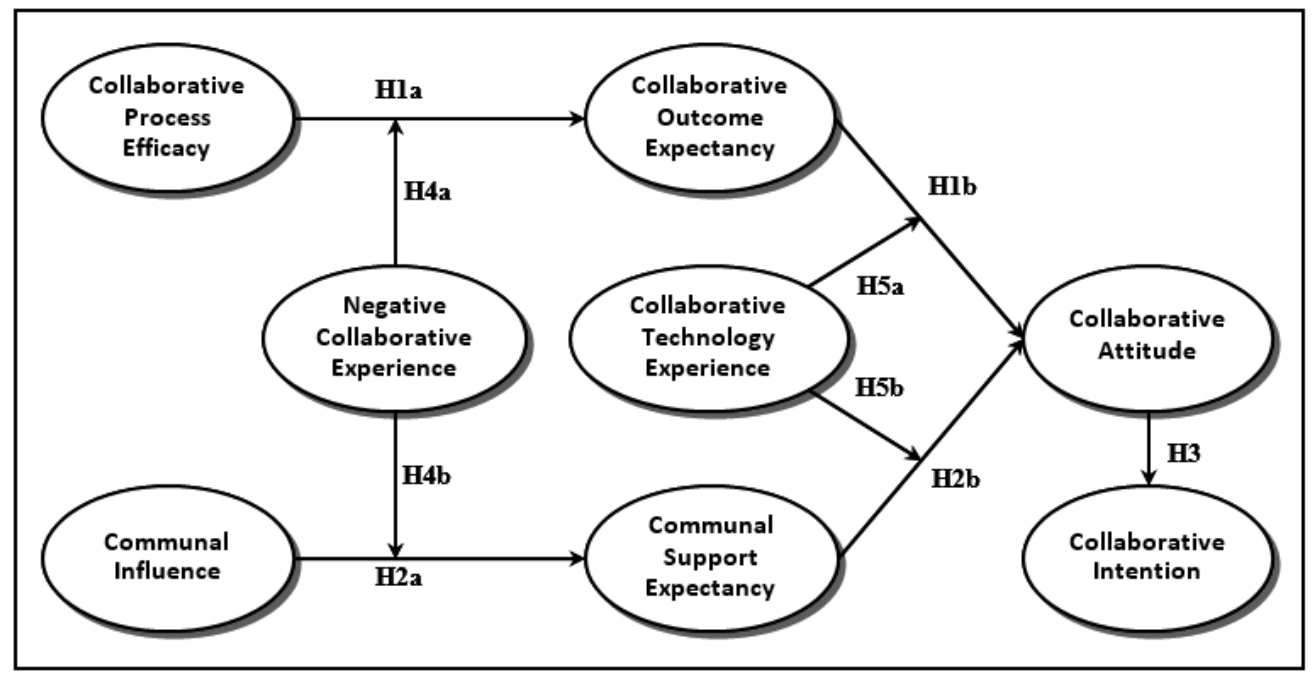




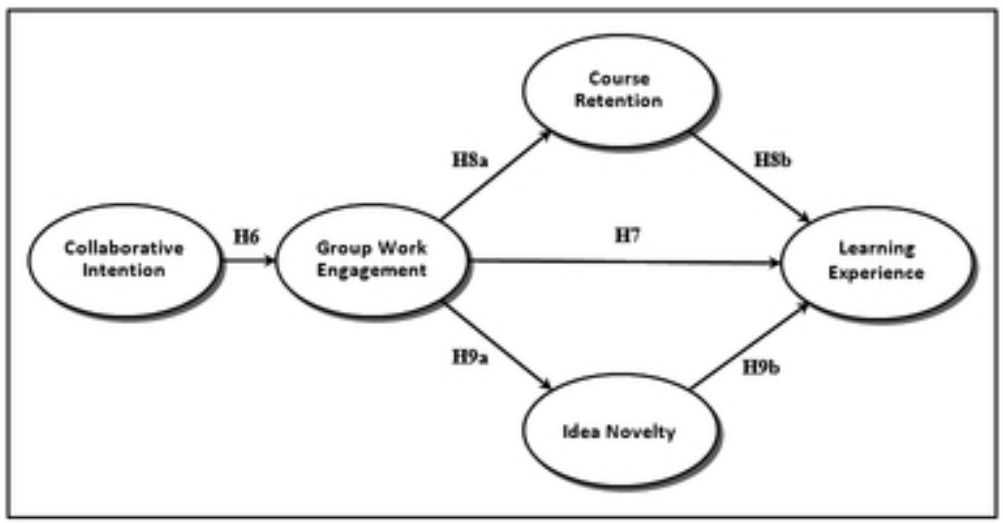

$16 \times 8 \mathrm{~mm}(600 \times 600 \mathrm{DPI})$ 


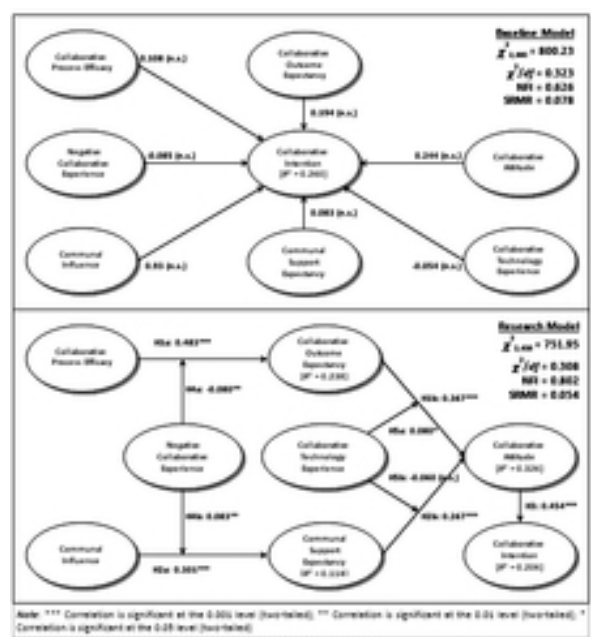

$9 \times 10 \mathrm{~mm}(600 \times 600 \mathrm{DPI})$ 


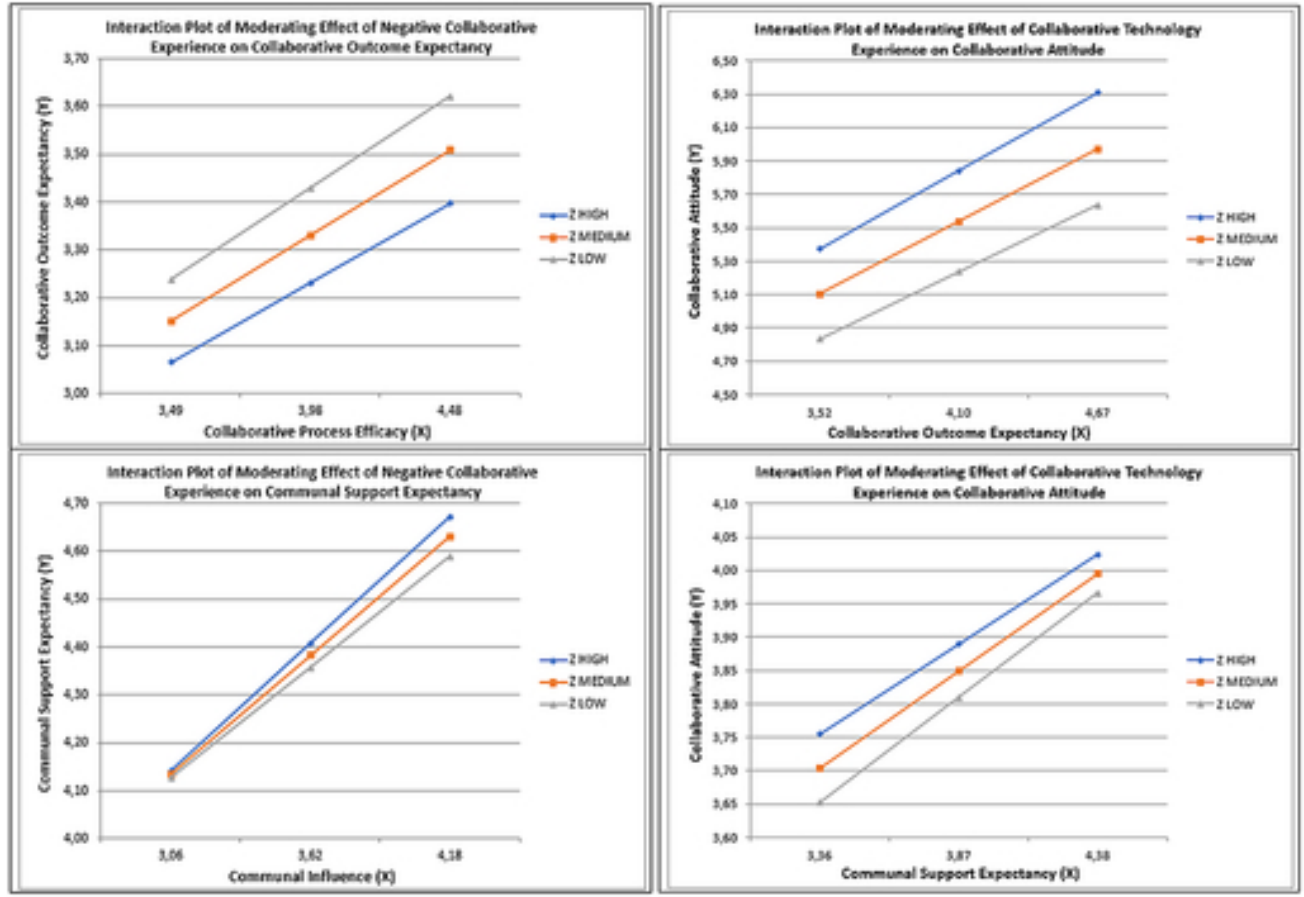

$21 \times 15 \mathrm{~mm}(600 \times 600$ DPI $)$ 


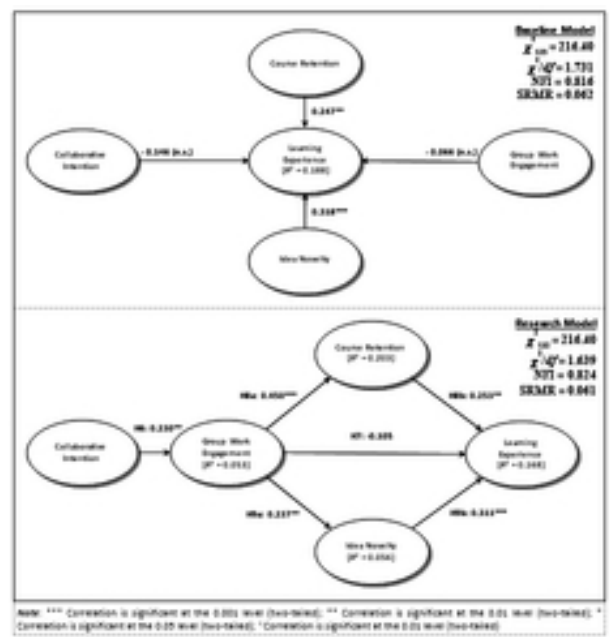

$9 \times 10 \mathrm{~mm}(600 \times 600 \mathrm{DPI})$ 